\title{
Molding the History of a Maritime Empire: The Role of the Thirteenth-century Mosaics of San Marco in Reforming the Venetian Past
}

Heather McCambly

Portland State University

Follow this and additional works at: https://pdxscholar.library.pdx.edu/mcnair Let us know how access to this document benefits you.

\section{Recommended Citation}

McCambly, Heather (2006) "Molding the History of a Maritime Empire: The Role of the Thirteenth-century Mosaics of San Marco in Reforming the Venetian Past," PSU McNair Scholars Online Journal: Vol. 2: Iss. 1, Article 27.

https://doi.org/10.15760/mcnair.2006.206

This open access Article is distributed under the terms of the Creative Commons Attribution-NonCommercialShareAlike 4.0 International License (CC BY-NC-SA 4.0). All documents in PDXScholar should meet accessibility standards. If we can make this document more accessible to you, contact our team. 
Portland State University McNair Research Journal 2006-2008

Molding the History of a Maritime Empire: The role of the thirteenth-century mosaics of San Marco in reforming the Venetian past

by

Heather McCambly

Faculty Mentor:

Anne McClanan

Citation: McCambly, Heather. Molding the History of a Maritime Empire: The role of the thirteenth-century mosaics of San Marco in reforming the Venetian past. Portland State University McNair Scholars Online Journal, Vol. 2, 2006-2008: pages [206-308]. 


\section{Molding the History of a Maritime Empire: The role of the thirteenth-century mosaics of San Marco in reforming the Venetian past}

HEATHER MCCAMBLY

ANNE MCCLANAN, FACULTY MENTOR

The mosaics of the Venetian Church of San Marco embody how this empire used imagery for political and ecclesiastical purposes. The church of San Marco is recognized as a force which drew the island fragments of primitive Venice into a unified city and empire. In indirect yet unmistakable ways this basilica mirrored the city's increasing self-confidence and power. These images were not merely decoration, but an independent argument in the nexus of Venetian spiritual and political power meant for all to see. ${ }^{1}$ San Marco as the chapel to the Doge and thus, all of Venice, was shaped "not so much by impersonal and largely unconscious trends and sentiments but by the conscious will of the ruling caste, whose representatives wanted it to be the visible symbol and the programmatic embodiment of their ideas." ${ }^{2}$ In short, we place stock in the images of San Marco and how they reflect societal trends, values, and changes because Venetians put stock in what images were constructed or changed in this structure. It is in the mosaics of the thirteenth century, after the conquest of Constantinople in 1204 that there is a metamorphosis of intent due to societal and political factors that will be the focus of this investigation. The mosaics of the thirteenth century represent a departure from previous traditions due to a changing political position; the imagery is altered to create a new layer of Venetian myth, which utilizes unique medieval concepts of history, time, and the will of God, in

\footnotetext{
${ }^{1}$ Thomas E. A. Dale, "Stolen Property: St Mark's First Venetian Tomb and the Politics of Communal Memory." Memory and the Medieval Tomb. Ed. Elizabeth Valdez El Alamo and Carol Stamatis Pendergast. (Aldershot, UK and Brookfield, VT: Ashgate, 2001), 211.

${ }^{2}$ Patricia Fortini Brown, "The Self-Definition of the Venetian Republic." City States in Classical Antiquity and Medieval Italy. Ed. Anthony Molho, Kurt Raaflaub, and Julia Emlen. (1991: The University of Michigan), 516.
} 
order to recreate Venetian history with roots in early Christianity and an even deeper sacred and ancient past.

This paper will examine the thirteenth-century mosaics by analyzing a variety of factors in the visual environment and the iconography of the mosaics themselves. First, I will examine briefly the nature medieval visuality and the previous architectural and artistic tradition within San Marco, moving then to analysis of the mosaics of the Old Testament cycle, the methods of transfer, and the model from which they were made. Next, I will explore the mosaics of the Cappella Zen and the South Transept as they pertain to the legend of Saint Mark. Last, I will present the historical context of the imagery in thirteenth-century Venice as well as the history of imitation and appropriation at San Marco. Finally, I will examine as a part of the historical context the medieval concept of time and history within the thirteenth-century environment, how it continues with and departs from prior traditions, and what this illustrates about the mosaics and the use of time and historical memory.

The first aspect which must be considered in this discussion is the role of imagery in the medieval context, a theme which must be established to lend legitimacy to the type of analysis presented in this paper. This factor plays a pivotal role in understanding the use of art or imagery in this culture, and asserts that imagery affects the medieval beholder and communal memory in a deep and legitimate manner. Without this assertion the argument that this imagery was used to mold the Venetian identity has no foundation. The fact that imagery and visual historical evidence be taken into account in our attempt to understand the ideas and images of cultures that are not predominantly linguistically trained has the "ring of an obvious truth or methodological necessity." ${ }^{3}$ In order to analyze any culture, medieval or otherwise, it is necessary to identify the "media of the culture in which we work," just as we would approach our own

\footnotetext{
${ }^{3}$ Margaret Miles, Image as Insight, (Boston: Beacon Press, 1985), 15.
} 
news and entertainment media to understand the beliefs, attitudes, and means of shaping modern American culture, so too must we find the equivalent in medieval culture. It is necessary to isolate the modes and content of public communication and the exchange of verbal or visual ideas, depending on the culture. ${ }^{4}$ In thirteenth-century Venice, no single center of media and communication can compare as far as importance, legitimacy, or even sheer exposure as the Basilica of San Marco.

In largely illiterate cultures such as the one in question, visuality was not the only means of communication, thus, other means such as sermons, extraliturgical drama and other sources auditorily available to audiences are often considered in medieval studies. In general, the images available in Christian communities, as the permanent and constantly available messages may be considered evidence of the messages that were likely received by other, auditory means. ${ }^{5}$ Images are a significant piece of the discourse in medieval Christian communities, and are more profound than the evidence of theological texts and simultaneously more superficial. They are more superficial in the sense that they were more available to historical people in the course of their daily lives, and could not, for obvious reasons, be as complex as a written theological argument. Images are more profound not in their complexity, but in their importance at the center of the life of the whole community. ${ }^{6}$

The essential importance of visual imagery and art in medieval thinking as a form of media and communication, the widest form in medieval culture, is evident and dominant throughout all of the Middle Ages. Despite its consistency, the nature of visuality also changes, although not in importance, throughout the medieval era. A major change between earlier and later medieval visuality and art affects the shape of the mosaics of San Marco in the thirteenth

\footnotetext{
${ }^{4}$ Miles, 28.

${ }^{5}$ Miles, 28.

${ }^{6}$ Miles, 29.
} 
century, as well as the type of viewing which would have been expected of the beholder. The early medieval visual experience can be described as received by an individual and focused on an instantaneous and powerful effect. ${ }^{7}$ In contrast, the visual experience in the thirteenth century and later is more clearly structured by physical and metaphysical ideas; the glance of earlier medieval beholders had shifted to a prolonged gaze and interactive experience. ${ }^{8}$ Art may have responded to this change, or more probably, helped to shape it by presenting more fragmented, "seductive," complex, or enlarged visions. Such images were not viewed with doubt, but required faith that such images represented divine truths, these were no longer the striking and symbolic images that acted only as cues for pre-existing memories of the early Middle Ages. Instead the thirteenth-century viewer was being challenged with imagery, such as that within San Marco, that took time, effort, and study. Within these images were truths that could shape a communal memory, or even the perceived history of a nation. ${ }^{9}$

What these two arguments assert concerning San Marco is that these mosaics must be considered as not only important and intentional indicators of the attitudes and desires in Venice at this time, but that they were noticed, understood, and important to the thirteenth-century viewers as well. In studying these mosaics it is safe to say that the images were as important as spoken or written language in creating this history and sense of foundation. ${ }^{10}$ This accessibility, the profound and widely viewed nature of the mosaics in the political and religious center of a growing Empire, did not escape the notice of either the viewer or the designer behind the images. When we consider these images we must do as Otto Demus suggested, and not view them as decoration which are indirectly important, but as vehicles for mass communication and

\footnotetext{
${ }^{7}$ Cynthia Hahn, "Visio Dei: Changes in Medieval Visuality." Visuality Before and Beyond the Rennaisance. Ed. Robert S. Nelson. (Cambridge, UK: Cambrdige UP, 2000), 169.

${ }^{8}$ Hahn, 169 .

${ }^{9}$ Hahn, 188.

${ }^{10}$ Constable, 7.
} 
for historiographic alteration, as intentional narratives or references that the designer knew would be contemplated and considered as factual by the viewers within the basilica. There was a degree of understanding, between the designer and the viewer, that the images presented in this venue were significant, that the early Christian references, the use of the Cotton Genesis model, the visual parallels and physical intersections between the Old and New Testament narratives and even the contemporary Venetian elements would not have gone unnoticed.

In early art historical study of Venice, it had been considered a "no-man's land" between the Byzantine tradition in the east and the Latin west. ${ }^{11}$ This quality at first seemed to historians an area of difficulty. However, these multiple references are now understood as the intent of the designers to draw from Roman Empires, east and west, in spinning a purely Venetian multilayered history. ${ }^{12}$ Through many mediums, ranging from political to visual, the Venetians have created a myth of origin and existence that draws carefully on sources with a heritage useful to the Venetian image. ${ }^{13}$ In the words of Gasparo Contarini, a sixteenth-century apologist of the Venetian Republic, "Venice, he that doth not see thee doth not esteem thee." 14 This is an interesting way to frame the study of Venice as a visual culture, one that addresses in a set of images how this state used visual messages to manipulate and shape the social imagination. ${ }^{15}$

In order to analyze this particular imagery we must first recognize the context of the church as a whole in order to grasp how this imagery functioned as a part of San Marco. The first San Marco (it is the third San Marco which now stands) was built, according to records,

\footnotetext{
${ }^{11}$ Otto Demus, "Venetian Mosaics and Their Byzantine Sources." Dumbarton Oaks Papers, 33 (1979), 337.

${ }^{12}$ Debra Pincus, "Venice and the Two Romes: Byzantium and Rome as a Double Heritage in Venetian Cultural Politics." Artibus Et Historiae 13.26 (1992), 102.

${ }^{13}$ James S. Grubb, "When Myths Lose Power: Four Decades of Venetian Historiography." The Journal of Modern History 58.1 (1986), 43.

${ }^{14}$ David Rosand, “Venetia Figurata: The Iconography of Myth” Interprezione Veneziane: Studi di Storia dell'arte in Onore di Michelangelo Muraru. Ed. Rosand, David: (Arsenal Editrice, 1984), 177.

${ }^{15}$ Rosand, "Venetia Figurata," 177.
} 
under the Doge Giustiniano Particiaco using stones from Equilo and Torcello. ${ }^{16}$ This reuse was not for economic reasons, but to incorporate important remains of the past from the terra firma into this new sacred and political building. This first building was constructed based on the church of the Holy Sepulchre in Jerusalem. ${ }^{17}$ The later addition from 1063, which is the shape known today, is based on the Apostoleion, or the Church of Holy Apostles in Constantinople. ${ }^{18}$ This was a reference not only to the prestige of Byzantium, but also that this was the same architectural form that housed Luke the Evangelist in Constantinople and John the Evangelist buried at Ephesus. ${ }^{19}$ The designers behind these architectural and artistic references were transferring widespread, historical and holy symbols from established centers of world devotion and power to the emerging power of Venice.

These examples of appropriation illustrate that from the foundation, visual references were made by copying foreign models to appropriate a sense of history and prestige that the new empire did not possess. ${ }^{20}$ Similar to the architecture, the mosaics of the earlier areas of the church are marked by a strong Byzantine influence. There were two main waves of mosaic installation, the first in the main chamber of the interior between the eleventh and twelfth centuries, and the second in the thirteenth century in the atrium of the basilica after the sack of Constantinople in $1204 .^{21}$ It is impossible to describe this extensive earlier cycle within the space of this paper, but it is possible to recognize the main attributes that contrast the later mosaics of interest (figure 1 and 2). The emphasis on Venetian themes shows that although San Marco was decorated in a Byzantine visual style, it was never using strictly Byzantine themes or iconography. The first and most apparent aspect of the interior was the mass of gold tesserae

\footnotetext{
${ }^{16}$ Ettore Vio, ed. The Basilica of St. Mark in Venice. (New York: Riverside Book Company, 1999), 35.

${ }^{17}$ Vio, 36.

${ }^{18}$ James McGregor, Venice from the Ground Up. (London: Belknap P, 2006), 33.

${ }^{19}$ McGregor, 34.

${ }^{20}$ Elizabeth Rodini, "Mapping Narrative at the Church of San Marco: a Study in Visual Story Telling." Word \& Image 14.1 (1998), 387.

${ }^{21}$ Jennifer J. Williamson, The Joseph Cycle in the Atrium of San Marco, Venice. (1996), 1.
} 
use that created a stark and abstract setting for the scenes of saints, angels, and narratives. These figures possess a strikingly Byzantine style, with traditional drapery patterns and postures instead of, the figures are iconic in their relative isolation within the backgrounds. ${ }^{22}$ These earlier mosaics covered most, if not all, of the important New Testament stories such as the life and passion of Christ, a cycle of the life of Mary, images of the saints and, most unique to San Marco, the life and translation of St. Mark. ${ }^{23}$ Making the imagery a reference to contemporary Byzantine art, not a reproduction of their art. In contrast, after the turn of the century the mosaics present a stark departure in meaning and form to these iconic images. ${ }^{24}$ This shift is imperative to understanding these thirteenth-century mosaics as a result of a change in the Venetian desire to use visual appropriation in a different manner.

The mosaics of the atrium of San Marco represent a continuous narrative of the Old Testament that holds within it many political, religious and typological references connected to the Venetian state. In some portions of the mosaics such as the Joseph cycle that spans three of the seven available bays within the atrium, references beyond Old Testament narrative seem to be blaringly apparent. In other areas such as the Creation Cupola the references are more subtle and seem to be limited to its strict reliance on the ancient model or the proto-renaissance style. This style is indicative of the wealth of Byzantine and early Christian spolia flooding Venice and specifically San Marco from the sack of Constantinople, as well as the desire to identify with the apostolic age. ${ }^{25}$ Overall the style of these mosaics is very inconsistent making it difficult but also unneeded to discuss them in any specific order, each bay or cupola represents a very specific style and level of emancipation from the model. Despite varying levels of symbolism

\footnotetext{
22 Otto Demus, The Mosaics of San Marco. Ed. Kessler S. Herbert. (Chicago and London, 1984). 146

${ }^{23}$ Demus, The Mosaics of San Marco, 3.

${ }^{24}$ Vio, 88.

25 Otto Demus, “A Renascence of Early Christian Art in Thirteenth-Century Venice.” Late Classical and Medieval Studies in Honor of Albert Mathias Friend, Jr. Ed. Kurt Weitzmann. (Princeton, New Jersey: Princeton UP, 1955), 349
} 
throughout the mosaics connecting Venice to an ancient past, there is a consistent presence, in all the mosaics, of meaning beyond basic narrative which signals the thirteenth-century Venetian desire to connect its comparatively shallow past with the apostolic age, and even the era of the Old Testament.

Not only were the visual references within this Old Testament cycle used to connect Venice to an ancient past, but the very basis for the mosaics, the model itself, offered value in the attempt of the designers to suggest ancient and holy origins. The very structure of San Marco was based on meaningful and ancient models, here, there is a new model chosen for the mosaics of the atrium, which went beyond former Byzantine models in favor of a manuscript which was most likely the Cotton Genesis, an early Christian manuscript. ${ }^{26}$ However, the determination of this book as a source is complicated by the fact that this manuscript was badly burned in $1731 .^{27}$ There are some remaining images available for investigation but all are charred, shrunken or otherwise damaged significantly (figure 3). There are also a few surviving copies of Cotton Genesis images done prior to the fire which provide insight into its original appearance (figure 4). ${ }^{28}$ The use of this model has complex implications which affect what the mosaic was meant to communicate within this civic and religious context. This is not the first use of a manuscript miniature as a model, as it has a long history dating to antiquity, yet its use on such a large scale highlights the importance and innovation of this program. ${ }^{29}$ The iconography and origin of the model implies a further depth of meaning in the mosaic, and how the references and deviations are used illustrate how something uniquely of thirteenth-century Venetian meaning was made from this early Christian manuscript.

\footnotetext{
${ }^{26}$ Weitzmann, “Illustrations in the Manuscript of the Septuagint,” 105.

${ }^{27}$ Lowden, 40.

${ }^{28}$ Kitzinger, 101.

${ }^{29}$ Weitzmann, "Illustrations in the Manuscript of the Septuagint," 106.
} 
The Cotton Genesis has been recognized as a possible source for the Genesis Cycle since J.J. Tikkanen's findings over a century ago, yet the use of the specific manuscript as a model has been a source of controversy among scholars. J.J. Tikkannen originally postulated that it was a close relative of the Cotton Genesis that was the model, and this tentative thesis was solidified in the studies of Weitzmann, Kessler and Demus. One scholar, John Lowden, in his analysis of the Cotton Genesis, in context to other early Christian manuscripts, insisted that this manuscript was an exception, not a norm, for early manuscripts, which may support the identification. ${ }^{30}$ He goes on to insist that the San Marco mosaics from this model are revealing about thirteenth-century taste rather then early Christian. ${ }^{31}$ This assertion, which may at first cast doubt on the use of this manuscript, does not suggest that the Cotton Genesis wasn't the model for the mosaics; rather it suggests an expression of the tendency to update or exaggerate images to fit modern idioms. ${ }^{32}$ Some scholars have indicated that Weitzmann's analysis in affirmation of the use of the Cotton Genesis, may have assumed the relationship and based his analysis on a supposition and not the evidence available. ${ }^{33}$ Kurt Weitzmann and Herbert Kessler explored the issue of the Cotton Genesis and San Marco extensively by studying the various manuscripts and works descended from the Cotton Genesis model, along with remnants from Cotton Genesis. These scholars concluded that every discrepancy from the Cotton Genesis found in the mosaics can be explained through the natural processes of translating miniatures to monumental decoration, or by changes required for translation to a thirteenth-century paradigm for iconographic purposes. ${ }^{34}$ In fact, areas of anomalous iconography in the mosaic coincide directly with scenes which had been missing in the Cotton Genesis, meaning the mosaicist had to create the scene sans

\footnotetext{
${ }^{30}$ Lowden, 51.

${ }^{31}$ Lowden, 42.

${ }^{32}$ Kitzinger, 109.

${ }^{33}$ Williamson, 14.

${ }^{34}$ Weitzmann, "Illustrations in the Manuscript of the Septuagint," 19.
} 
model. ${ }^{35}$ They assert that "the differences between the manuscript that has survived and the mosaics dissolve when considering the overwhelming similarity of the two." 36

Ernst Kitzinger weighs into the debate by citing the worth of this manuscript as a possible reason for the variations; it was so valuable that it would have stayed out of chaotic areas such as the worksite, meaning mosaicists worked from sketches of the model, to cartoons, to mosaic. ${ }^{37}$ Deviations from the model may be cited, but these appear to have been made so that these early models would be more typological in nature, an important aspect in this study of the Creation Cupola and thirteenth-century mosaics. Due to the extensive damage done to the manuscript, it is difficult to ever say conclusively that there may not have been a model similar to the Cotton Genesis which could have been used. However, one can speculate that it is implausible that there was a manuscript of such great worth and rarity as the Cotton Genesis, as available and useful to the Venetians at the beginning of the thirteenth century. ${ }^{38}$

Furthermore, the origin and trail of ownership of the Cotton Genesis is a disputed point as well. Deborah Howard asserts that this manuscript was most likely made in Alexandria at the end of the conversion period in the fifth or the beginning of the sixth century. ${ }^{39}$ This origination in Alexandria stands out, as St. Mark was the first Bishop of Alexandria, and the home of his relics until the theft by Venice. ${ }^{40}$ A questionable inscription inside the fly-leaf of the manuscript has led to discussion about whether it was brought directly to Venice from Alexandria through active trade relations in Egypt, or if it was part of the spolia taken from Constantinople in 1204. ${ }^{41}$ Either origination has worth to the Venetian identity as a model for these mosaics, either as a link to Byzantium or St. Mark, and a connection to early Christianity in either case. Yet the

\footnotetext{
${ }^{35}$ Weitzmann, "The Place of Byzantine Manuscript Illumination,," 20.

${ }^{36}$ Weitzmann, "Illustrations in the Manuscript of the Septuagint," 19.

${ }^{37}$ Kitzinger, 108.

${ }^{38}$ Demus, The Mosaics of San Marco, v. 2, 141.

${ }^{39}$ Lowden, 49 and Howard, 80.

${ }^{40}$ Howard, 80.

${ }^{41}$ Weitzmann, "Illustrations in the Manuscript of the Septuagint," 6.
} 
prevalent allusion to Egypt may be viewed as an affirmation of Egyptian origin, seen in all four domes of the north wing of the atrium. The prominence of Egyptian settings, specifically those of Joseph inside the atrium, further emphasize the land of St. Mark and Christian justification of temporal power, especially in regions of scarce resources. ${ }^{42} \mathrm{~A}$ further benefit to this imagery is that Venice prided itself on management of scarce resources, a theme in much of San Marco. ${ }^{43}$ Through the use of this model, from an eastern, early Christian tradition, Venice was reaching beyond contemporary Byzantine reference, and attempting to create a civic identity tied to this piece of early Christian past. ${ }^{44}$

Key in understanding the concepts concerning the use of this model is the manner in which these images were transferred, translated, and chosen to become part of the dome mosaic, which illuminates the intent of the imagery. Weitzmann indicated ten principles of transmission from the model to monumental. Due to the depth of these principles it is only possible to present a summary, yet even this is helpful in understanding the process and importance of the scenes in the atrium. Six of the principles are in some way connected to the use of space and seem to go hand in hand: "alteration of format," "condensations," "conflations," "compositional changes," "omissions," and "selectivity." 45 Although, omissions could be made for iconographic purposes, it was often an issue of space. The Cotton Genesis had around 500 original illustrations, while the mosaics originally presented 113 scenes from this manuscript, thus only scenes of utmost importance to the main stories had priority, as did those with symbolic meaning to the site such as ties to Egypt or other determining factors. ${ }^{46}$ These are attempts to utilize space, either by combining scenes to include all important imagery while

\footnotetext{
${ }^{42}$ Howard, 103.

${ }^{43}$ Howard, 81.

${ }^{44}$ Howard, 103.

${ }^{45}$ Weitzmann, The Mosaics of San Marco, v. 2, 107-8.

${ }^{46}$ Weitzmann, The Place of Book Illumination in Byzantium, 18.
} 
maintaining visual cohesiveness, or by rearranging parts of a composition to define and centralize the scene. Also, the scenes in the Cotton Genesis were flexible in height but were fixed in width, while the frieze-like mosaics had flexible width and fixed height. This combined with needs to economize free space and omit unneeded or difficult to fit details account for these principles. $^{47}$

In contrast to the previous principles, the "additions" principle is not concerned with issues of space, and is much rarer. In very few instances were whole scenes added from outside the model. ${ }^{48}$ The two principles of "iconographic changes" and "stylistic changes" are very important to the art historical study of the San Marco mosaics. Other principles offer understanding of the basic transmission of a miniature image to a large scale, while these two principles highlight the updating of style for political purposes. These indicate that although the use of this model in the mosaics had iconographic benefits in itself, providing a sense of ancient connection, changes were also made to enhance the meaning of these images. The first blatant example of iconographic change is made in the scene of the Judgment of Adam and Eve, which has been put into a composition not developed until the Middle Byzantine period for scenes of the Last Judgment. This was the first of many drastic changes, as the designer became more accustomed to using and changing the model to fit thirteenth-century Venetian trends or political desires. Most of the changes made to the iconography, like this, were made to enhance the Venetian relevance, typological or similar elements in the mosaics.

The use of typology began in the time of the Cotton Genesis and was present in the miniatures, and the exaggeration of these themes, was fitting to San Marco's use of historical connections that had begun prior to the thirteenth century. The final principle of change is that of the "process of transmission from one medium into another," which summarizes Kitzinger's

\footnotetext{
${ }^{47}$ Weitzmann, The Mosaics of San Marco, v. 2, 108.

${ }^{48}$ Weitzmann, The Mosaics of San Marco, v. 2, 107.
} 
assertion above that a manuscript of this cost would have hardly been present on scaffolding. ${ }^{49}$ Thus the transmission from miniature, to sketch, to wall by itself could cause a series of changes. ${ }^{50}$ Overall these principles serve to enhance our understanding of how a model such as the Cotton Genesis could be used and offer a richer meaning because of the origin of the images, without absolute adherence to the images within the model. The use of the Cotton Genesis offered worth as an Egyptian and early Christian manuscript, and was molded to not only fit the space but further enhance thirteenth-century Venetian needs, as in the inclusion of the Moses narrative, the Egyptian emphasis, and other such changes to better communicate the intended concept concerning Venetian destiny.

Previous to the thirteenth-century developments which affected the imagery at San Marco, and brought about the shift in imagery, the elasticity of Venetian culture can be seen in the transition to identifying St. Mark as patron saint. Formerly it was St. Theodore who was the patron saint of Venice, a Byzantine warrior saint. ${ }^{51}$ It was neither chance nor the stolen relics of St Mark that began his reign as patron to Venice, but rather the traces he left behind during his possible ministry in the nearby city of Aquilea. ${ }^{52}$ Venice lacked the important Roman origins shared by most other powerful Italian cities, and the furta sacra of Mark's relics was designed to compensate for this historical deficiency. ${ }^{53}$ This theft was similar to the sacking of Constantinople and the stolen relics of the true cross, various imperial spolia and possibly the Cotton Genesis, all of which laid a Venetian claim to Constantinople's cultural heritage. The ability to claim a connection to Mark was an ecclesiastical foundation, independent from that of Rome,

\footnotetext{
${ }^{49}$ Weitzmann, 108.

${ }^{50}$ Weitzmann, "Illustrations in the Manuscript of the Septuagint," 18.

51 Dale, "Inventing a Sacred Past," 58.

52 Dale, "Inventing a Sacred Past," 55.

53 Dale, “ Stolen Property,” 105.
} 
which could only be accomplished through a direct connection with the apostolic age. ${ }^{54}$ It was a status which Alexandria held due to St. Mark's history, and which the Bishop of Aquilea vied for in order to claim both independence as well as jurisdiction over all of northeast Italy. ${ }^{55}$ Venice, after a time of struggle for power with Aquilea, asserted its victory through the acquisition of the relics as well as use of images, which were as powerful, if not more so, then written propaganda in this culture. These relics and images, as well as the creation of myth, turn this Egyptian apostle and founder of the Aquilean church into the most visible symbol of the Venetian church and state. ${ }^{56}$ Later, in the era of the Creation Cupola this story of translation to Venice changes to one of predestination, just as Byzantine reference is discarded in favor of early Christian, so is the claim to St. Mark's legacy.

Both chronologically and in narrative order the first mosaic scene is the Creation Cupola. This is the earliest of the mosaics to be discussed in this paper, and in contrast to iconography in other areas of the atrium or in the narratives concerning St Mark, it appears to lack importance due to the absence of any substantial Venetian references in terms of the iconography. Yet, the importance of this dome, when studying the rest of the thirteenth century, stands in the fact that it is part of an evolution in thirteenth-century representations. The model itself, which will be discussed further, has significant meaning in the connections being forged between contemporary Venice, St Mark, and even the Old Testament, as a manuscript of the Old Testament, of early Christian creation, with ties to both Byzantium and to Alexandria, the home of St Mark. In the period of the installation of the Creation cupola there is a much stricter adherence to the model then in later mosaics where the model is used, yet often used with more liberty to make more clearly Venetian references. Even so, here in the dome most adherent to

\footnotetext{
54 Dale, “Stolen Property,” 205.

55 Geary, 130.

${ }^{56}$ Dale, “Inventing a Sacred Past," 102.
} 
the model there are clear changes made to the manuscript model in favor of images which invoked clear typological connection, and this unique Christian understanding of time and history. It is this deviation from the model in the first dome of the atrium which sets the stage for the manner in which time or history was used and understood in order to illuminate the changes made in later atrium mosaics as well as the narratives of St Mark elsewhere in the basilica which place the status and events of contemporary Venice in an ongoing Christian or biblical history. Just as events at the creation of the world could foreshadow later biblical and New Testament events, so too could events in the Old Testament foreshadow the fate and role of Venice in the thirteenth century.

The Creation dome (figure 5) covers the events from the Creation of the World to the Expulsion of Adam and Eve, or the first three chapters of Genesis. ${ }^{57}$ In three concentric strips, the frames of the miniatures were eliminated resulting in a continuous and often overlapping flow of scenes, which are horizontally separated by writing, a very rare configuration. ${ }^{58}$ The sequence begins around an ornamental disc in the middle of a gold ground and moves downwards. The first ring of mosaic is of the five scenes beginning with the Spirit above the $W$ ater to the Creation of the Plants. The second ring of eight scenes begins just under the first scene of the first ring, representing the Creation of the Firmament up to the Introduction of Adam into Paradise. The third frieze, with no less then twelve scenes, some being conflated or combined, begins with the Naming of the Animals and ends with the Expulsion, with the four cherubim in red and blue on all sides in the pendentives. ${ }^{59}$ Outside the entire dome runs an inscription which refers to the

\footnotetext{
${ }^{57}$ Weitzmann, The Mosaics of San Marco, 108.

${ }^{58}$ Demus, "Venetian Mosaics and Their Byzantine Sources," 145.

${ }^{59}$ Weitzmann, The Mosaics of San Marco, v. 2, 110.
} 
cherubim in the pendentives that may represent the cherubim stationed outside of paradise to guard the Tree of Life, all four of which retain their original color scheme of red and blue. ${ }^{60}$

It is probable that the atrium program was planned all at once and not in the more improvisational nature of other earlier mosaics. ${ }^{61}$ There are also indications that this dome was made from the central medallion down the sides of the dome, with gold being laid in concentric circles in between figures and landscapes. ${ }^{62}$ Additionally, an aspect of departure from previous mosaics is in the arrangement of the scenes, the three friezes contrast to the normal treatment used since antiquity, a single circular sequence of images near the base of the dome. ${ }^{63}$ The detailed nature presents an overwhelming wealth of images; the most densely packed of all the domes in the atrium, which expands on many scenes that are often compressed in previous visual imagery. In these compact scenes the use of landscape, architecture, complex forms, layers, and modeling, or even purposefully archaic clumsiness, are much more prominent then in earlier mosaics, just as the array of colors in atrium mosaics had increased. ${ }^{64}$ This increase in color was possibly from an influx of materials from Constantinople, and from a desire to follow the narrative and complex nature of the early Christian model. ${ }^{65}$ There was an overall decorative wealth of shape and color, as seen in the Creation of the Birds and Marine Creatures (figure 6), which retained a rich use of gold without the previously dominating quality. ${ }^{66}$

In the first scene of the cupola, the Spirit above the Waters (figure 7), the spirit is represented by the dove with spread wings. The dove, which is a symbol of the Holy Spirit, is out of place in this Old Testament scene. This is just the first of many Christian elements which

\footnotetext{
${ }^{60}$ Demus, The Mosaics of San Marco, v. 2, 76.

${ }^{61}$ Hawkins, Ernest J., and Liz James. "The East Dome of San Marco, Venice: a Reconsideration." Dumbarton Oaks Papers 48 (1994), 232.

${ }^{62}$ Demus, The Mosaics of San Marco, v. 2, 126.

63 Demus, The Mosaics of San Marco, v. 2, 145.

${ }^{64}$ Demus, The Mosaics of San Marco, v. 1, 169.

65 Demus, The Mosaics of San Marco, v. 1, 4.

${ }^{66}$ Demus, The Mosaics of San Marco , v. 2, 168.
} 
suggest the typological manner, in which the Bible in the Middle Ages was often interpreted, especially in the twelfth and thirteenth centuries, as a living connection which could be fostered through a visual environment. ${ }^{67}$ The disc behind the dove has the form of an aureole, in three concentric circles that invokes the three circles of the dome, symbolic of the Trinity. ${ }^{68}$ The next scene of the Separation of Light from Darkness (figure 8) introduces another Christian image, that of Christ-Logos as Creator (figure 9), with a golden halo overlapped by a silver cross holding a staff with a mounted cross. ${ }^{69}$ Light is represented in red and darkness in blue, important color imagery throughout the dome, which is a foreshadowing of the fall and redemption to come. ${ }^{70}$ The angel present at the separation is caste partly in darkness, actually changing colors to blue. This suggests that the battle between good and evil that began with the separation of the good and fallen angels began on the first day of Creation and was allowed by God for the creation of free will. $^{71}$

Within the discs of light and darkness we can make out three rings once again, a reference to the Trinity, and six rays coming out corresponding to the number of active days in creation. ${ }^{72}$ The color symbolism continues throughout the dome and represents its reflective nature, each ring predicting the others, the fall of Adam and Eve and the redemption of the New Testament. As an example of this predictive nature we see the Creation of the Plants, the Admonition of Adam, and the Expulsion all lined up and seeming to point to one another. ${ }^{73}$ This shows how each image, although made from a model, was subtly changed and placed to suggest an interpretation popular in the twelfth and thirteenth centuries. This interpretation is of

\footnotetext{
${ }^{67}$ Giles Constable, Culture and Spirituality in Medieval Europe. (Variorum, 1996), 51.

${ }^{68}$ Demus, The Mosaics of San Marco, v. 2, 77.

${ }^{69}$ Weitzmann, The Mosaics of San Marco, v. 2, 37.

${ }^{70}$ Penny Jolly Howell, Made in God's Image? Eve and Adam in the Genesis Mosaics At San Marco, Venice. (Berkeley and Los Angeles: University of California P, 1997), 16.

${ }^{71}$ Howell, 17.

${ }^{72}$ Demus, The Mosaics of San Marco, v. 2, 77.

${ }^{73}$ Howell, 26.
} 
antitypes in the Old Testament as points of proof that the Old Testament was made as a precursor to the New, and to assert the divine wisdom of God. ${ }^{74}$

Moving to the scene of the Creation of the Plants, we are given one of the best links in this image to its model, the Cotton Genesis which will be discussed below, through the surviving drawings of the Third Day of Creation. The connection between the two is clear the only changes are due to issues of space, and clarification. ${ }^{75}$ In addition to establishing similarity, these drawings provide a basis for exploring the changes made. Although iconographically similar, the format is drastically changed due to space limitations. These changes include a reduction of the number of trees in order to clarify the trees of most importance (the Trees of Life and Knowledge). The Tree of Knowledge is often shown in blue in the mosaics, an iconographic change to emphasize the color symbolism in the dome. In this scene we can also decipher a greater concern with reality in the mosaic than in the Cotton Genesis through striation lines in the garments of Christ that have changed to a natural rendering of folds. To an opposite effect, the mosaicists did not incorporate the colorful atmospheric setting which was part of the antique tradition of the Cotton Genesis, in favor of a Byzantine gold background, a method used to depict a sense of the divine. Until the Naming of the Animals (figure 10), a scene which is also representative of a search for Adam's mate, we continue to see the use of a surreal and holy golden background, which afterwards changes to a more mundane vision of earthly foliage. This suggests that although the mosaicists used an identifiable model, they were also manipulating the images subtly away from the model and Byzantine reference in order to communicate ideals of typological reference.

\footnotetext{
${ }^{74}$ Robin M. Jensen, "The Fall and Rise of Adam and Eve in Early Christian Art and Literature." Interpreting Christian Art. Ed. Heidi J. Hornik and Mikeal C. Parsons. (Macon, Georgia: Mercer UP, 2003), 52.

${ }^{75}$ Kitzinger, 101.
} 
In the second ring of mosaic there is a dynamic scene of the Creation of the Birds and Marine Creatures in which the antique origin of the Cotton Genesis is evident. ${ }^{76}$ This specific emphasis may also suggest the interest of the Venetians in their marine surroundings. In the next scene of the Forming of Adam and the Animation of Adam (figures 11 and 12), a two-stage creation which has been connected to Roman tradition, has changed from the Cotton Genesis which used a four stage depiction. This decrease may have been to enhance the meaning behind the most important scenes: the creation of his body and the gift of his soul or animation. ${ }^{77}$ One of the most important aspects of difference in the mosaic is introduced here, that of the enthroned creator, which was not an aspect of the original Cotton Genesis. This intentional addition of the creator enthroned is part of an emphasized them of a powerful and infallible God, this counteracts the theme in the "J text" of the Bible which represents the creator as unaware and out of control of his creation. The images in this dome and in much of the atrium assert the intent of God in biblical and historical events, the presence of the throne, and many other images in this dome, hints at this prophetic and infallible nature.

In the first scene of the third ring it is apparent that this creator has not lost his power to his creation as is indicated in the "J text" of the Bible. ${ }^{78}$ Instead, he has delegated it, as seen in the Naming of the Animals, where the Creator, now seated in his throne (not a part of the model), uses the speaking gesture of the right hand to encourage the man to prove his superiority by naming the animals. ${ }^{79}$ Adam gestures in the same right handed manner, by placing a hand on the lion, king of animals and sign of St. Mark. ${ }^{80}$ As discussed previously, this is the scene where the new setting begins, no longer the holy gold setting but a more realistic landscape, a transition to

\footnotetext{
${ }^{76}$ Demus, The Mosaics of San Marco, v. 2, 110.

${ }_{78}^{77}$ Demus, The Mosaics of San Marco, v. 2, 111.

${ }^{78}$ Howell, 23.

${ }^{79}$ Howell, 38.

${ }^{80}$ Henry Maguire, "Adam and the Animals: Allegory and the Literal Sense in Early Christian Art." Dumbarton Oaks Papers 41 (1987), 365.
} 
the fall from grace that would result from the creation of Eve. The animals here are more combined than in the Cotton Genesis, appearing almost as single two-headed beasts, a feature which may be used to highlight the difference of Adam, a single rational being without a mate. ${ }^{81}$ The separation of Adam's mate may result in an effect similar to the separation of darkness from the light, the creation of evil.

As the fateful figure of Eve enters this story many deviations are made from the model to predict the evil to come. The scene of the Creation of Eve (figure 13) is in two parts, the Taking of the Rib and the Forming of Eve, the first occurrence of a two-scene frame. ${ }^{82}$ There are many complex elements to the iconography and symbolism of this and many scenes that cannot be explored in full depth. Some major changes may be investigated, including the inversion of the scene from the Cotton Genesis, where Adam appears to the left of the Creator in the scene, and the Creator is shown in profile, which is a sign of evil in medieval iconography. ${ }^{83}$ Furthermore, a rib from the left side, or evil side, is taken and a tree is seen sprouting from Adam's wound. This is a common aspect of this scene and the suggestion that the perfection of paradise is tainted by the creation of Eve. ${ }^{84}$ The sleep of Adam, which seems to have antique origin in the sleep of Endymion, is suspect as well, as sleep in medieval thought was a sign of a suspension of rational thought in favor of sensual motivation. ${ }^{85}$ The looming blue tree of Knowledge is present in the forming of Eve, just as the Tree of Life was present in Adam's formation, a sign of this separation of opposites, evil out of good. In the formation of Eve, the Creator is shown with his hand on her wrist and a finger pointing down to her pudendum, when in the formation of Adam he points to his head. This asserts Eve's carnality, as does the omission of her animation, and

\footnotetext{
${ }^{81}$ Howell, 29.

${ }^{82}$ Demus, The Mosaics of San Marco, v. 2, 113.

${ }^{83}$ Howell, 32.

${ }^{84}$ Howell, 33.

${ }^{85}$ Howell, 33.
} 
her eventual downfall due to her sin. This also signals that God had foreseen, even as he made her, that "Eve bore history within her womb" as postulated by St Augustine. ${ }^{86}$

After Eve's creation in the Introduction of Adam and Eve (figure 14) there is a reversal of Adam's position from the Naming of the Animals. He is now for the first time at the picture's left, an ill omen. ${ }^{87}$ Also, in the touching of Eve's shoulders similar to the touching of the Lion's head, we see a connection with thirteenth-century palpable gestures, and concern for realism. ${ }^{88}$ As the imagery is investigated Lowden's assertion becomes evident, that this dome is as much a reflection of the thirteenth century as it is the Cotton Genesis. ${ }^{89}$ In the scenes of the Temptation of Eve, Eve Plucking the Fruit and Giving It to Adam, and the Denial of Guilt (figure 15), there are many consistencies with the Cotton Genesis, including the use of the fig as the Tree of Knowledge. Yet, there are also major departures from the Cotton Genesis, including the use of the enthroned Creator and the omission of the serpent in the Denial of Guilt. These two changes seem to leave the blame on Eve and Eve alone, while reinforcing the consistent omniscience of the Creator. ${ }^{90}$ Again in the Giving of Fruit to Adam, Eve stands in the position of the Creator, but in profile signaling great evil. ${ }^{91}$

After the couple is aware of their nakedness and has been found by their Creator, in the Judgment of Adam and Eve (figure 16), there is a complete reconfiguration of the Cotton Genesis scene to a Last Judgment composition as discussed..$^{92}$ In this scene, a reference is made beyond the judgment of these two people referring to the judgment of all humanity, a conflation of time and narrative to depict a typological reference. Finally, in the Expulsion (figure 17), the Tree of

\footnotetext{
${ }^{86}$ Howell, 40.

${ }^{87}$ Howell, 44.

${ }^{88}$ Demus, The Mosaics of San Marco, v. 2, 114.

89 John Lowden, "Concerning the Cotton Genesis and Other Illustrated Manuscripts of Genesis." Gesta 31.1 (1992), 42.

${ }^{90}$ Demus, The Mosaics of San Marco, v. 2, 115.

${ }^{91}$ Howell, 48.

92 Weitzmann, “The Place of Byzantine Book Illumunation,” 18.
} 
Life with the cross protruding from it stands behind the Creator in Paradise. This may be of specific importance due to recent acquisition of the true cross by Venice. ${ }^{93}$ Along with the tree are two red phoenixes, a reference to Christ and the red or light left behind the flaming sword of the cherubim directed to guard paradise. Adam and Eve are shown erect and gesturing with left hands towards their new land, Eve is the most emphatic, gesturing to Adam at this new world that the medieval viewers associated with her. She uses the same gestures as the Creator when he introduced Adam into Paradise. ${ }^{94}$ God pushes on their backs, down and to the picture's left, out of the gates in a composition similar to a scene of the Damned entering the Mouth of Hell in medieval compositions.

Once the couple has entered the earthly realm, they face their punishments in the scene of the Labors of Adam and Eve (figure, 18). In this scene Adam meets his punishment of death and toil on the land, and Eve meets hers, child labor, submission and desire for her husband. ${ }^{95}$ Although Adam is shown in backbreaking labor, Eve is represented in a throne-like seat wearing a blue fillet and blue belt around her waist, daringly voluptuous compared to her prior mundane curves in paradise, her distaff like a scepter, the Queen of the earthly realm, a complete reworking from the model. ${ }^{96}$ Her majesty reminds the viewer of a queen to come: the Virgin Mary. This Mariological reference is similar to the references in medieval art, and in the book of Romans, of Christ as the new Adam. ${ }^{97}$ The woman who closed the door to paradise would, through her cursed womb, make way for the woman who could open that door again. ${ }^{98}$ Here ends the narrative of the Creation Dome with the most recognized, but not only, typological

\footnotetext{
${ }^{93}$ Howell, 56.

${ }^{94}$ Howell, 57.

${ }^{95}$ Genesis, 3:16-19

${ }^{96}$ Howell, 58.

${ }^{97}$ Romans, 5:14.

${ }^{98}$ Jensen, 44.
} 
reference which highlights a uniquely Christian sense of time and history particularly rich in the setting of San Marco.

There is a great wealth of imagery in this dome, yet the selected images present the general picture of what this dome was meant to communicate. The use of the Cotton Genesis had meaning in itself, but the thirteenth-century popular theology concerning the origin of evil, typology, and the nature of Eve were incorporated to present not only a historical image, but also one of purpose within the visual context of San Marco. I argue that the deviations or exaggerations from the Cotton Genesis model such as that of the first days of creation and the origin of evil, the use of color symbolism, character placement, and other areas are used not just to imply the origin of evil as in Eve, but are also used as a typological theology and a unique Christian view of history and time. Despite a reliance on the analysis of this dome by Penny Howell, my main contention does not merely concern the issue of the representation of women and the intended message of the evil of Eve as a sign of the current misogyny. This use of imagery and typology is only begun in the exaggerations and references here in the Creation Cupola, and continue with growing intensity and reference to Venice as the Old Testament cycle is developed and adjusted throughout the thirteenth century.

These mosaics display how the story of Adam and Eve, and understanding of the Old Testament had evolved from the time of the early Christian model. No longer was it seen as simple narrative, but as a reference to the fall and the redemption to come, similar to the predestination of Mark's relics. ${ }^{99}$ From the first day of creation, signs of evil make themselves known, as did signs of the reversal with the coming of Christ. These are anagogical forms and can be seen in nearly every scene of the Creation Cupola as in the Trees of Life and Knowledge, the use of Christ as Creator, the presence of the Cross, imperial imagery, Christological or

\footnotetext{
99 Jensen, 26.
} 
Mariological references. In the end these references are used to bear witness to the presence of God's wisdom and master plan even when it appears to be in a disaster of $\sin .{ }^{100}$ What was once narrative in the Jewish tradition, and to an extent in earlier Christian traditions, has now become proof of God's plan. The fact that these images are not based in the Old Testament text is of little concern to the Venetian mosaicists, as the distinction between the eras of past, present or future were very thin. ${ }^{101}$ To change the order of history, either religious or civic, especially for a higher cause was seen as not only acceptable but God-willed, as seen in the evolution of typological imagery in this cupola, and further emphasized in later images in the atrium as well as the Cappella Zen.

This imitation and deviation in the images of the Creation brings up many preliminary and fascinating questions about what sort of connections can be drawn from this use of "topoi," or imbuing of meaning in all things through typology. An interesting connection, which will be explored further, are the changes made in the imagery of the narrative of St Mark in the Cappella Zen in the 1260 's. ${ }^{102}$ Not only could St. Mark's relics, as a living entity, will themselves to a new home, but the story was refashioned to visually assert the predestinatio legend. ${ }^{103}$ This is reminiscent of the way the Genesis cycle used imagery to assert that the New Testament occurrences were destined from the beginning, weakening Jewish and all other claims to the scriptures. This refashioning put stock not only in the common belief of the living nature of relics, but in the malleability of history and the use of typology to explain a holy past. ${ }^{104}$ The simultaneous installations of these mosaics seem indicative of the heightened desire for historical connection in this period. They were creating a sense of a destined path to greatness and a

\footnotetext{
100 Jensen, 52.

${ }^{101}$ Constable, 50.

${ }^{102}$ Thomas E. A. Dale,"Inventing a Sacred Past: Pictorial Narratives of St. Mark the Evangelist in Aquileia and Venice." Dumbarton Oaks Papers, 48 (1994), 89.

${ }^{103}$ Maria Georgopoulou, "Late Medieval Crete and Venice: an Appropriation of Byzantine Heritage." The Art Bulletin 77.1 (1995), 479.

${ }^{104}$ Dale, "Stolen Property," 212.
} 
usurpation of the role of both Constantinople and Rome in their ecclesiastical and political power and independence.

As we examine the Creation Cupola and its place within San Marco, it is tempting to dismiss this set of mosaics in comparison to the blatant rewriting of history seen elsewhere in the church. Yet in the story of creation, fall, and expulsion, we are reminded that Venice is using a concept of time that was already a part of the Christian historical view. Begun in early Christianity with the typological references of the Cotton Genesis, and exaggerated in the twelfth and thirteenth centuries, the Bible and holy past were seen as alive and able to shift to ecclesiastical or cultural needs. The notion that holy history, from stories to relics, lived and chose their fate hundreds of years later, is one that is not unique to San Marco, nor is a careful management of history. Realignment of the past for civic or religious needs, which were often blurred, was a practice that through legend, prophecy and typology could be seen as God-willed events. Every aspect of imagery was used for propagandist purposes, as was the reference to early Christianity through the Cotton Genesis model; it abandoned Byzantine references, in favor of early Christian connections. Thus, a prominent shift has taken place in Venetian imagery in this period, from a desire to reference dominant political powers, to a desire to take ownership of their heritage. All facets, from the choice of the model to changes that enhanced the typological nature of the scenes, should be considered of relevance in understanding the desires and beliefs of the Venetians in the thirteenth century.

After the dense narrative of the Creation Cupola, and its use of thirteenth-century typological images, the images of the narrative of Cain and Abel are not only withdrawn from the riches of Paradise but withdrawn from the intense narrative and isolated on a gold ground. The narrative pace is allowed to slow in order to highlight the importance of the Election of 
Abel. ${ }^{105}$ The narrative begins in the East Lunette of the South Bay, just below the Creation Cupola, and begins with the Begetting of Cain (figure 19), ending in the West Lunette of the South Bay with the Curse of Cain (figure 20). Just as in the Creation narrative there is a strong sense of doom to the narrative witnessed by the beholder, through the gestures and placement of Adam and Eve, and the scenes of the Begetting of Cain versus that of the Birth of Abel (figure 21), it is apparent even in infancy what the fate of these brothers will be. ${ }^{106}$ This narrative foreshadows its end of the disinheritance of the eldest son in favor of the younger brother, a theme in this Old Testament cycle, shown in the Curse of Cain (figure 22), and further in the Murder of Abel. This aspect of the Old Testament cycle in San Marco, along with the Egyptian, Chosen People, and wise and just rule themes are varyingly bold and subtle but ever present, and suggest Venice and her people as part of this living narrative of the people of God. The Sacrifices of Cain and Abel are Eucharistic in representation and again signify the Christian understanding of time as a series of divinely appointed events which provide antitypes to types to come. ${ }^{107}$ This concept of typology is further emphasized in the narrative of Cain and Abel by the inscription which has been altered from the biblical text, it reads "Christ accepts Abel and rejects Cain." the worthier, younger brother is not only an Old Testament standard or convention but one of the Apostolic era being embraced by Venice at this time.

Continued in the Abraham cupola, the theme of the inheritance of the younger son, in the choice to omit typically Christological stories such as the Sacrifice of Isaac, in favor of emphasis on Abraham's rejection of the Jews and joining the Gentiles as well as the choice of Isaac over Ishmael. This mosaic set is located in the Second Cupola, in the west wing of the

\footnotetext{
${ }^{105}$ Dale, "Inventing a Sacred Past," 95.

106 Howell, 76.

107 Demus, “The Mosaics of San Marco” v. 2, 157.

${ }^{108}$ Dale, "Inventing a Sacred Past," 95.
} 
atrium, and has, like many of these mosaics, experienced extensive restoration. ${ }^{109}$ The narrative begins with the Lord speaking to Abraham, in a manner which echoes the visions of the first Joseph Cupola and even Mark in the Cappella Zen, referring to a destiny in the future which would forsake eldest sons, or eldest cities in favor of the worthier choice. Despite beginning the narrative with the prophecy of the birth of the destined and chosen son of Abraham, Ishmael became the first born. The cupola ends with the Circumcision of Ishmael, followed by the Circumcision of all Men, with no sign of the promised son to come. ${ }^{110}$ Separated from this antiHebraic narrative of Abraham and Ishmael, come the scenes of Isaac in the lunettes.

In the East Lunette the scenes of Abraham Meeting the Angels, and the Hospitality of Abraham are depicted, these along with the images of the Birth and Circumcision of Isaac (figure 23) from the West Lunette fulfill the prophecies of God from the Dome. This unique approach to the story of Abraham concludes this chapter of the narrative, leaving out the main Christological scene mentioned previously, a rare and noticeable omission in this era of Old Testament "vogue." "111 Just as the unusual focus on the Joseph narrative must be seen as an intentional decision based on the current needs and desires of the Venetian state, so too must this unique approach to the story of Abraham and his sons be seen as intentional and important to understanding the overall meaning and tone within this cycle and general works within this unique creative period.

Similar to the foreshadowing of Cain and Abel's fate, as well as the inscription in the narrative of Christ's acceptance and rejection, this scene is begun with the promise to Abraham concerning his younger son. In fact, a total of fifteen Genesis scenes were skipped in order to

\footnotetext{
109 Demus, “The Mosaics of San Marco” v. 2, 138.

${ }^{110}$ Demus, “Mosaic Decoration of San Marco,” v. 2, 138.

${ }^{111}$ Demus, "Renascence of Early Christian Art," 350.
} 
present his prophecy at the beginning of the narrative. ${ }^{112}$ After many skipped scenes which highlight further the birth of Isaac, an inscription again associates the chosen, younger son, not with God the Father but with Christ, it reads "Abraham stands for Christ, who, after repudiating the Hebrew people, joined the Gentiles and became one with them." ${ }^{113}$ This passage parallels St Paul's interpretation of the two sons of Abraham in Galatians 4:21-31, where Ishmael and Isaac are seen as an allegory for the Jews, who are slaves to the Old Law, and the Gentiles who have become the new people of promise, similar to those given throughout this cycle signaling the promise of God's will to the younger or worthier son. ${ }^{114}$

Furthermore, the fate of Cain and Ishmael are further signs of God's justice, justice pr the separation of good from evil, is a theme not only of San Marco but of Venice as a whole. Even in the prominent presence of the story of Noah's drunkenness and the son who left his father naked versus the son who covered his father is a possible parallel to the justice which Venice saw in herself. ${ }^{115}$ It is important to assert that it would be inappropriate to see this theme of justice as a separate theme or entity from that of the typological references to the New Testament and modern Venice, or Zwei-Bruder theology. In essence the themes and beliefs held or created in this period concerning the role of Venice in this line of Christian history is attached to the notion of justice and the passing of inheritance to a worthy recipient. Venice is usurping the role of Mark's Alexandria and the sacred past held within that city, as Alexandria had fallen into the hands of the Saracens by this time and was no longer deserving of the honor of Mark's legacy. ${ }^{116}$ Just as Cain was unworthy due to his poor sacrifices, Ishmael was unworthy based on the unfaithfulness of Abraham to God's promise in his conception, Ham beholding his father's

\footnotetext{
112 Weitzmann, “The Illustrations in the Manuscripts of the Septuagint,” 125.

113 Dale, "Inventing a Sacred Past," 95.

${ }^{114}$ Dale, "Inventing a Sacred Past," 95.

115 Howell, 84.

${ }^{116}$ Patrick J. Geary, Furta Sacra. Princeton: Princeton UP, 1990, 93.
} 
nakedness, or the unrighteousness of Joseph's brothers, so too was Alexandria unworthy due to Venice's predestination to hold the sacred legacy of the Evangelist, but also due to its neglect of the Christian faith and theoretically of Mark himself. ${ }^{117}$

These themes are actively connecting the current state of Venetian power and political decisions with biblical and Old Testament models, a method which contributed legitimacy to the state of thirteenth-century Venice. By connecting the fate of Venice in the thirteenth century with not only early Christianity, but with model and patterns of the Old Testament, the Venetians draw on a particular medieval concept of typology. Typology, although derived from a certain way of interpreting biblical events, was also a way of viewing the will of God in history, rulers, kings and nations were set in place intentionally, by God, thus God left traces of nature and intention throughout historical and biblical narratives. Although the events of the Old Testament were not believed to has led to the events of contemporary Venice, they were seen as intention precursors, and signs of God's nature, just as events of the Old Testament did not all lead directly to the crucifixion and resurrection of Christ, they were seen as reflections which could legitimize and strengthen the claim of Christianity to the heritage of the Old Testament. In these mosaics, despite variation of style over time, there are consistent themes in the narratives of Cain, Abel, and Abraham of justice, God's divine will and predestination, and the inheritance of the younger son, which are consistent to the vast narrative of Joseph as well as the mosaics of the Cappella Zen in the South Vestibule. In addition to these larger themes, the antiHebraic tone in the Abraham Cupola supplements the meaning behind these narratives, which is emphasized by the auxiliary images to the narrative in the pendentives supporting the cupola. ${ }^{118}$ These inscriptions of the prophets of Isaiah and Ezekiel characterize the Jews as rebellious and fallen people whom God is going to turn from in favor of a new people of the promise instead

\footnotetext{
117 Geary, 93.

${ }^{118}$ Demus, “Mosaics of San Marco,” v. 2, 157.
} 
of a people of the law. ${ }^{119}$ This model parallels the rising prominence of Venice, not only as a gentile nation, but as a rising Christian power, literally overtaking the roles held previously by Rome and Byzantium. These themes along with the Christological inscriptions indicate a sense of God's will and justice consistently throughout the mosaics, the foreshadowing of evil, and the triumph of a worthier brother. They complement the new history being forged for Venice in the predestinatio mosaic of the Cappella Zen, which mirrors these mosaics of the Old Testament. ${ }^{120}$ There is a visual connection being made between the power and actions of Venice in acquiring the relics, conquering Constantinople and other territories, to the biblical tradition of the predestined inheritance of a worthier son. Hence the importance of the ties to Alexandria, Venice was not disregarding the role of Egypt but using the images and legacies of it to claim an inheritance, similar in a way to those seen in the atrium mosaics.

Despite the unique approaches and qualities to the Venetian mythogenesis, or mythic foundation, Venice is not alone in history or even in Medieval Italy in attempts to legitimize current institutions of church or politics through carefully constructed visual images or historical record. ${ }^{121}$ One example of a parallel to the Old Testament mosaics of San Marco and how they tie into contemporary developments involving the Venetian state and the translation of Mark's relics may be seen in the early thirteenth-century fresco program of the crypt in Anagni Cathedral near Rome. ${ }^{122}$ In Venice the Old Testament cycle connects in various ideological and physical ways to the Cappella Zen or façade mosaics, but in Anagni there is a direct physical parallel within the church between the translation cycle and Old Testament cycle as they run parallel, one above another. There is a similar thematic juxtaposition being drawn here in San Marco, in not only the transfer of inheritance from one brother to another but also the journey

\footnotetext{
${ }^{119}$ Demus, “Mosaics of San Marco,” v. 2, 157.

120 Dale, "Inventing a Sacred Past," 96.

${ }^{121}$ Pincus, "Venice and the Two Romes," 109.

122 Dale, "Inventing a Sacred Past," 96.
} 
of the Chosen People into Egypt with Joseph and back out to the Promised Land led by Moses. $^{123}$

Within the thirteenth-century mosaics of San Marco, one inescapable aspect is the prominence of the theme of Egypt and the life and story of Joseph. Of the seven cupolas of the atrium, three focus on the life of Joseph (figures 24, 25, 26), two of which focus solely on the events in Egypt. Otto Demus, in his analysis of this era in thirteenth-century Venice after the Fourth Crusade, has discussed the status of Venice as one similar to "a man without a shadow," meaning a state with no history, or at least compared to the rest of the medieval world. ${ }^{124} \mathrm{He}$ proposes that Venice's solution to this issue was to "fake one." ${ }^{125}$ Here in the emphasis on the Joseph mosaics, as with all mosaics of the atrium, we see the employment visual imagery to create a new communal understanding, or memory, of the origins and purpose of the Venetian state, the potency of this visual method of affecting history and memory "cannot be overstated." ${ }^{126}$ We are then led to question in what manner the atrium mosaics as a whole are used to manipulate the concept of Venetian history and self-imaging. Laying claim to a sacred past was a powerful way to legitimize current civic institutions, something that was no doubt intended within San Marco as a representative of both church and state in Venice. ${ }^{127}$ What the iconography of the Joseph cupolas, and more importantly the sheer over-representation of these scenes within an Old Testament setting, imply is that St. Mark was destined for both his mission into Egypt and martyrdom in Alexandria, as well as his return to Venice. Venice is in a sense a "Promised Land," and thus a predestined world power religiously, and as the emphasis on wiserule implies, a temporal power as well. The mosaics of the Cappella Zen assert the divine will

${ }^{123}$ Dale, "Inventing a Sacred Past,” 97.

${ }^{124}$ Demus, "A Renascence of Early Christian Art," 353.

${ }^{125}$ Demus, "Renascence of Early Christian Art," 353.

${ }^{126}$ Stephen Lamia, "Synaesthesia, and the Sepulcrum Domini: Sensory Stimuli and Memory Stratagems." Memory and the Medieval Tomb. Ed. Elizabeth Valdez El Alamo and Carol Stamatis Pendergast. (Aldershot, UK and Brookfield, VT: Ashgate, 2001), 27.

${ }^{127}$ Dale, "Stolen Property," 205. 
behind the presence of Mark in Venice, while the mosaics of the Joseph cycle not only further emphasize this destiny but also reaffirm the role of the Venetian state and people, as the "Chosen People" of Mark, further legitimizing the power and purpose of the state while also providing a model for and highlighting the effectiveness of the Doge.

These mosaics were put in place beginning in the third quarter of the thirteenth century, a time which Demus recognizes as the height of this Venetian "proto-renaissance," or time of reviving archaic, classical, styles for purposes of suggesting a new history. ${ }^{128}$ The Joseph narrative occupies three of the six cupolas in the north wing of the atrium. These Old Testament mosaics of the atrium represent the most consistently sustained effort in the direction of connecting with the apostolic age, specifically with the history and memory of St. Mark. ${ }^{129}$ Each bay in the Joseph narrative is its own entity, each with separate parts of the narrative, but also very separate styles, including a twenty to thirty year gap between the installation of the first cupola and the second and third cupolas. ${ }^{130}$

The first cupola represents the youth of Joseph through being taken up to Egypt, beginning with Joseph's Dream and ending with his Lament. The second bay represents Joseph's troubled life in Egypt, recording his early career in Egypt, which begins with Joseph Sold to Potiphar (figure 27), and culminating in the North Apse in Pharaoh Making Joseph Governor of Egypt. Finally, in the third bay his triumph in Egypt is depicted, beginning with Joseph Gathering Corn (figure 28), and ending with Joseph Having Simeon Bound, showing scenes of his wisdom, clairvoyance and justice to his brothers. He is shown in this cupola in his new role as a leader, second only to the Pharaoh; this cupola is followed by the Moses Cupola and the Exodus of the Chosen People from Egypt.

\footnotetext{
${ }^{128}$ Demus, "Renascence of Early Christian Art,” 359.

${ }^{129}$ Demus, The Mosaics of San Marco, 94.

${ }^{130}$ Demus, Mosaics of San Marco, v.2, 157.
} 
The state of preservation of the bays vary, the best preservation being the third cupola, which despite being dirty with loose tiles appears to be completely original in both style and iconography. ${ }^{131}$ In the first and second cupola, Demus asserts that although poor preservation has at times changed the originality of the style, the general iconography and content is trustworthy and is most important to the arguments concerning the intent of the mosaics within San Marco. ${ }^{132}$ Each narrative begins in the east axis, the first and second cupolas begin with white lines, and the third has no indicator of the beginning. ${ }^{133}$ The style and content varies, the color palettes change between each cupola, and the colors vary significantly as do the sizes of the patches of color. The central medallions vary in size and decoration between each cupola, the size of the figures, the use of gold, the use of inscription, and the quantity and nature of the architectural settings vary between all cupolas. We will discuss here examples of iconography and the changing nature of the content as they pertain to the overall intent of the mosaics as a set. Yet it is not necessary to analyze each scene or element of style, as much of the style change is connected not to changing ideals or changing artist groups or even designers, but a progression of style as the ability to translate miniature to monumental becomes more developed. ${ }^{134}$

The mosaics of the Joseph cupola despite their variation do seem to be more "readable" than previous mosaics groups such as the Abraham cupola. The figures are larger, descriptive text is larger and more reduced, scenes are more clearly delineated, and overall there is a feeling of the instructive and moral value that Joseph narratives often held in the thirteenth century. ${ }^{135}$ The figures have taken on a much more classical and less awkwardly archaic appearance in comparison to the Abraham mosaics, with more lyrical movements and psychologically

\footnotetext{
${ }^{131}$ Demus, The Mosaics of San Marco, v. 2, 165.

${ }^{132}$ Demus, The Mosaics of San Marco, v.2, 155.

${ }^{133}$ Demus, The Mosaics of San Marco, v.2, 166.

${ }^{134}$ Demus, The Mosaics of San Marco, v. 2, 156.

${ }^{135}$ Demus, "The Mosaics of San Marco," v. 2, 156.
} 
influenced compositions making it tempting to speculate a new artist or designer is at work in some or all of these bays, however, this speculation is unnecessary as these are more signs of the constant progression towards a more sober style from that of the Creation Cupola. This seems to be the last step in this progression as the designer emancipated the style of the mosaics from the style of the Cotton Genesis model towards tendencies of the period while using the general content and iconography of the Cotton Genesis. This continuity is supported in the mosaics of the prophets in the pendentives of the Abraham bay and those in the Joseph bays. ${ }^{136}$

Scholars have focused on different aspects of the Joseph mosaics, although few appear to be contrary to one another. I will discuss here a few of the important theories and implications of these theories pertaining to the meaning and importance of the impressive status given Joseph in the atrium of San Marco. Thomas E.A. Dale has presented his rich analysis of the Joseph mosaics in his frequently cited article "Inventing a Sacred Past: Pictorial Narratives of St. Mark the Evangelist in Aquilea and Venice.” Another scholar which I will explore is Deborah Howard in her recent work "Venice and the East," in which she highlights the importance of the Eastern world beyond Byzantium on not only San Marco but Venice as a whole. ${ }^{137}$ Finally, I will discuss the thesis of Jennifer Williamson of Washington State University whose complex thesis synthesizes some of the hypotheses of Demus and Dale, as well as adding research which suggests additional themes in the Joseph mosaics.

Thomas E.A. Dale in his research on the narratives of St Mark in both Aquilea and Venice investigated how visual imagery, often together with other political, literary or historical chronicles, changed over time to suit the needs of either Aquilea or Venice concerning the legend of St. Mark. As mentioned previously, Dale concludes that in the shaping of narrative in

\footnotetext{
${ }^{136}$ Demus, “The Mosaics of San Marco,” v. 2, 156.

${ }^{137}$ Dale, Thomas A. "Inventing a Sacred Past," 100.
} 
this period the Old Testament mosaics play a significant role, especially those of the narrative of Joseph. These new pictorial narratives, including the predestinatio legend in the Cappella Zen, are forging closer links directly to the evangelist hedging out Aquilea and other factors which negate the divine connection between Venice and St Mark. ${ }^{138}$ Dale focuses on three aspects: the theme of the inheritance of the younger son, the emphasis on the Egyptian Sojourn, and the role of Joseph as Chosen Ruler. These themes are part of the effort to advertise the possession of the Cotton Genesis, a manuscript from Mark's Alexandria, but this alone cannot explain the shape of this program and specific emphasis on Joseph. ${ }^{139}$ Venice is identifying itself as the "younger brother," who will receive the transferred inheritance of the older, and the prominence of this type of narrative, emphasizes this.

The story of Joseph, like the predestinatio in the Cappella Zen and the Abraham Cupola, begins with a dream or vision by which Joseph learns of his destiny. ${ }^{140}$ The story concludes not with the last Joseph Cupola, but with the story of Moses. The narrative of Moses is not included in the Cotton Genesis, but inserted in this cycle in order to strengthen the allusion to the history of the Chosen People by ending with the Exodus from Egypt to the Promised Land. This parallels how St Mark's relics were destined for Egypt, only so they could be brought out to the "Promised Land" of Venice, to the home of the new "Chosen People."141 The Egyptian emphasis and importance on the inheritance of the younger son seem to be connected in intention, in order to highlight the importance of Egypt to St Mark and thus Venice. They also serve to emphasize the story of the Exodus of the Chosen People to the Promised Land, which draws attention to the transfer of this pattern in the translation of Mark's power to a "younger brother," or Venice, in the exodus of Mark to the land of the Venetians.

138 Dale, “Inventing a Sacred Past," 85.
139 Dale, “Inventing a Sacred Past," 95.
${ }^{140}$ Dale, “Inventing a Sacred Past," 96.
${ }^{141}$ Dale, “Inventing a Sacred Past," 96. 
The last theme Dale discusses concerns the connection between Joseph and the temporal power of Venice, specifically that of the Doge. Since the fourth century, Joseph has been praised as a model of good government in the church, and beginning in the sixth century, during the reign of Theoderic, has been praised as a model due to his clairvoyance, wisdom, and providence. The focus on Joseph as a model to the Doge is furthered by the references to good leadership in this branch of the atrium through the depiction of the virtues Justice, Charity, and Hope, as well as the prophets and saints which will be discussed further in the research of Williamson. These three virtues are discussed in an inscription in the Cappella San Clemente, which is directed to the Doge, and are embodied throughout the space of the Joseph narrative. $^{142}$

Beyond the discussion of the imagery and themes within the Joseph mosaics, there is the element of the placement of this specific narrative of the Chosen People. At the northwest corner of the atrium, there is an intersection of the Joseph cycle and the translation cycle of Mark's relics. An interesting intersection in itself, yet at the point where these two meet there is a depiction of the Doge as custodian of Mark's relics (figure 29). The imagery of the contemporary power of the Doge is connected with both the translation of Mark's power from Egypt to Venice, as well as the depiction of the narrative of the Chosen People, an antitype to the Venetian destiny. The very power of the Doge, and thus Venice, comes from his possession of the relics and this sacred history of Mark, as is depicted again in the Porta di Sant'Alipio. ${ }^{143}$ The Porta di Sant'Alipio is located directly behind this portal, the narrative of the Chosen People, the just rule of Joseph, and the Exodus to the Promised Land, which seems to signify a prophecy of the foundation of Venice as the "Chosen People" of St Mark following the

\footnotetext{
${ }^{142}$ Dale, "Inventing a Sacred Past," 97.

${ }^{143}$ Dale "Inventing a Sacred Past," 98.
} 
translation of his relics from Alexandria. ${ }^{144}$ This connection between the Doge, modern Venice, the Apostolic Age, and the Old Testament not only represents a theme of predestination, but a living connection with the present. This is a piece Biblical history living in modern Venice, as the cycle of the atrium connects with the predestinatio in the Cappella Zen, which is prefaced by the mosaics of the façade and the welcoming of Mark's relics. ${ }^{145}$ The mission of Mark was foreshadowed by the patriarchs of the Old Testament, prophesied by Mark's vision in the predestinatio, and fulfilled in the rededication of the city to Mark upon the arrival of his relics. ${ }^{146}$

Venice in the thirteenth century was presenting a special place for herself within the scheme of salvation, a predestined power and people, which is more difficult to examine or solidly analyze then the previous quasi-legal twelfth-century proofs concerning Aquilea. The impetus for this shift in interpretation came from the conquest of Constantinople in 1204 and the subsequent occupation of the Eastern Empire until $1261{ }^{147}$ This divinely sanctioned destiny asserted by the pictorial narratives did not stand alone but was contemporary with the Venetian chronicles of Martino da Canal as well as the fragmentary chronicle of Marco from 1290, both of which redefined Venetian history, and include the legend of the predestinatio. These writings were meant, like the mosaics, to bolster Venetian pretensions to world power following its assumptions of control over portions of the Byzantine Empire. ${ }^{148}$ This was a ground-breaking time for Venetian historiography when the city's recent past was being placed into a broader context of sacred history. ${ }^{149}$

Deborah Howard's interpretations may enrich the arguments of Dale concerning the importance of Egypt in these cycles. Howard notes that not only is the theme of Egypt

\footnotetext{
${ }^{144}$ Dale, "Inventing a Sacred Past," 98.

${ }^{145}$ Dale, "Inventing a Sacred Past," 99.

${ }^{146}$ Dale, "Inventing a Sacred Past," 99.

${ }^{147}$ Dale, "Inventing a Sacred Past," 100.

${ }^{148}$ Dale, "Inventing a Sacred Past," 10.

${ }^{149}$ Dale, "Inventing a Sacred Past," 100.
} 
overrepresented, but other elements important to the typological symbolism typically present in Old Testament cycles such as the story of Isaac or that of Jacob are omitted. ${ }^{150}$ The importance of Egypt and the justification of temporal power are emphasized on the exterior of the north atrium as well, in the relief of Alexander the Great, founder of Alexandria and the ruler of an enormous empire, Alexander may be intended as an image of temporal power with specific reference to Alexandria. The legend of the death of Alexander, and the return of his body to its rightful resting place by divine powers is similar to that of Mark and fits well with this theme of typological representation. This offered an image of classical analogy for the fate of Mark's relics as well as an image of the state, an image from the very location that the relics, which are the source of the Doge's power. ${ }^{151}$ Howard goes on to discuss the importance of the model, the Cotton Genesis, and its Alexandrian origin which whether true or mythical give this set of images a poignant relevance. ${ }^{152}$ Some scholars, including Hugo Buchtal postulate that this book may have even been brought directly from Alexandria giving it further significance. ${ }^{153}$

Overall, Howard sees the emphasis on Egypt as well as the Joseph narrative as directly connected to the temporal power of Venice and the Doge. ${ }^{154}$ The connection between Alexander, Joseph, and Mark made in San Marco would not have gone unnoticed by viewers, according to Howard, and this created a connection between the sacred power granted Venice by the relics of Mark, the tradition of the wise and just leadership of Joseph, and the destiny of Mark to come out of Egypt to reside with the new Chosen People. ${ }^{155}$ The importance and connection held between Egypt and the Doge were not merely through Mark's relics, but also through the example of Joseph, both may be seen as powerful and influential states which must

\footnotetext{
${ }^{150}$ Deborah Howard, Venice and the East. (New Haven \& London: Yale UP, 2002), 79.

${ }^{151}$ Howard, 80.

${ }^{152}$ Howard, 80.

${ }^{153}$ Howard, 81.

${ }^{154}$ Howard, 80.

${ }^{155}$ Howard, 81.
} 
mindfully manage scarce and inconsistent resources, an ability which the Doge's success relied heavily on. Also, through the biblical inscriptions in the mosaics about Joseph's power in Alexandria, a connection between Joseph and Mark is forged, as Mark inherited the role of Joseph, making Joseph a prototype of the first Alexandrian Bishop. This may arguably create a composite image for the Venetian Doge, between the wise and just temporal rule of Joseph and the holy leadership of St Mark.

Beyond representing images of a good ruler, these mosaics may also evoke a set of memories, either personal or retold, of this distant land and mythical origin of Venetian power. ${ }^{156}$ We see in these mosaics as noted by Demus, that the Cotton Genesis model is embellished to include more vivid settings and architectural backgrounds which create an Egyptian or foreign reality. There are numerous examples ranging from the colorful and airy pavilions in the scene of the Temptation by Potiphar's Wife, or the exotic and eclectic skylines surrounding the enthroned Pharaoh beneath a cusped arch, or the pyramid-like granaries which were once cones in the Cotton Genesis. Even the inscriptions seem to be simplified to a point where even the barely literate could identify the foreign and Egyptian origin of these landscapes. ${ }^{157}$ Howard mentions a final twist to her discussion in the labeling of the Midianites bringing Joseph to Egypt as merchants linking the event to traders, commercial power, and in a sense to Venice. ${ }^{158}$

The investigations of Jennifer Williamson focus again on the importance of Joseph as a model for the Doge, but also how auxiliary images such as Virtues, Saints, and Prophets emphasize these themes, and how the particular Doge, Doge Lorenzo Tiepolo, in power may

\footnotetext{
${ }^{156}$ Howard, 80.

${ }^{157}$ Howard, 81.

${ }^{158}$ Howard, 81.
} 
have imbued personal meaning into these mosaics. ${ }^{159}$ Williamson illuminates further the previous uses of Joseph in art, as a figure of a model leader, as seen on the throne of Maximian, or at times as a Christological figure. ${ }^{160}$ Previous to the mosaics of San Marco an example of a direct connection between a leader and Joseph can be seen in the Royal Monastery at Sopocani which connects their Prince directly to an image of Joseph. ${ }^{161}$ This connection is similar, according to Williamson, to the connection drawn in the Joseph mosaics to Doge Lorenzo Tiepolo and his role in the grain famine of 1268.

Aside from this specific connection made between Joseph and this particular Doge, the strongest emphasis remains on a general message of a wise and just example of temporal rule. ${ }^{162}$ Many elements echo the history of Venice in general, including the parallel between Joseph's destiny to rule in his vision at the beginning of the cycle as it corresponds to the destiny of Venice to hold the sacred power of St Mark in his visions in the Cappella Zen. There is also an overrepresentation within the cycle of his just behavior and decisions including his binding of his brethren, where other examples of this narrative skip these scenes entirely. ${ }^{163}$ Also, the images concerning grain, an important concern to the Venetians, are not highlighted for its profit as Joseph sells the grain to the Egyptians, but instead focuses on his foresight and wise rule to have provided for his people, just as the Doge would have wished to be viewed by the Venetians.

In addition to the narrative of Joseph in these three bays, there are also auxiliary images of virtues, saints and prophets. The virtues represented are Justice in the first dome, Charity in the second, and Hope in the third. There is one virtue in each bay, isolated in the apex,

\footnotetext{
${ }^{159}$ Williamson, 8.

${ }^{160}$ Williamson, 25.

${ }^{161}$ Williamson, 28.

${ }^{162}$ Williamson, 33.

${ }^{163}$ Williamson, 35.
} 
highlighting these themes of leadership as they are declared to the Doge in the Cappella di San Clemente. ${ }^{164}$ The prophets in these domes serve to prefigure and witness the events of the New Testament, but also to highlight specific themes, there are four prophets in three of the bays of the North Atrium. In the pendentives of the Abraham cupola Ezekiel, Isaiah, Daniel, and Jeremiah speak of warning and wrath. In the pendentives of Joseph I the figures of Nathan, Habakkuk, Eli, and Samuel emphasize justice and just actions, and in the last set present in the Moses Cupola the prophets represent the future coming of Christ. ${ }^{165}$

Due to the unique role of San Marco, as the private chapel of the Doge, it was here, after election the Doge, that he was crowned over the relics of St Mark. Hence, the iconographic schemes in this place highlight the role of the Doge and his connection to church devotion and to the people, done here in many ways through the Joseph mosaics. In the timeframe of these mosaics, efforts were being made to limit the power of the Doge who had previously been the Primus Venetorium, or the most powerful man in Venice and by the end of the thirteenth century his power will have decreased to Primus inter Pares, or first among leaders. ${ }^{166}$ In this time period it became a practice, beginning with Doge Jacopo Tiepolo in 1230, for the Doge to make specific pledges to the people after his election, including pledges concerning grain supply. ${ }^{167}$ In 1268 , during the era of the second and third Joseph Cupolas, under the reign of Doge Lorenzo Tiepolo a great grain famine hit. After which further safeguards were put in place which ensured grain supply and Venetian dominance over the Adriatic and subjection of Lombardy. ${ }^{168}$ This began a war which Martin da Canal attributed and justified due to the callousness of the other

\footnotetext{
${ }^{164}$ Williamson, 39.

165 Williamson, 41.

${ }^{166}$ Williamson, 68.

${ }^{167}$ Williamson, 73.

${ }^{168}$ Williamson, 77-78.
} 
states during the famine. ${ }^{169}$ This was a catalyst of the Venetian terra firma campaigns, thus grain became associated with Venetian stability. This connects Venice further to Joseph, as he was the first literary and possibly historical figure to put provisionary policies for grain in place. ${ }^{170}$ Joseph provided a model for just and wise rule, justification for leadership and foreign policy tactics of the Doge, and an ancient sanction for the power and leadership of Venice.

These various scholars highlight the manner in which this mosaic program was related simultaneously to the ancient past of the Old Testament, the apostolic age, and the recent past and present of the Venetian state. St Mark's relics provided connections with a sacred past, and rights associated with that past. The Old Testament references to Egypt, temporal power, and the Chosen People acted in the Joseph narrative to strengthen those sacred rights. ${ }^{171}$ This use of foreshadowing in the Old Testament events of the apostolic era and even of contemporary Venice was feasible and understandable by the beholder as the line between what was past, present or future did not have the same separate and definitive lines as in the modern era. This made interplay between them more active, Biblical history could continue through the "Chosen People" of Venice. ${ }^{172}$ Just as Constantine had his relics of the True Cross, so too did the Doge of Venice hold his power in his relics of St Mark, making Joseph a symbol which bolstered the basis of the Venetian power and invented history. ${ }^{173}$

The multiple themes of these mosaics including Egyptian emphasis, Venice as the "Promised Land" of St Mark, Joseph as a justification of temporal power, and the inheritance of the younger brother as it pertains to Venice's inheritance of Mark's relics, all tie Venice and the power of the Doge to ancient power both secular and religious. The existence and power of the

\footnotetext{
${ }^{169}$ Williamson, 78.

${ }^{170}$ Williamson, 79.

${ }^{171}$ Constable, 25.

${ }^{172}$ Constable, 171.

${ }^{173}$ Dale, "Stolen Property," 211.
} 
Republic was being portrayed as divinely willed in this period, and presenting the situations and power structures of Venice as mirroring those of the Old Testament, the apostolic age, and even through Alexander, of the classical period. Images could bind the past with the present, in a sense activating a cultural memory or understanding of a communal history which could bond ancient Christian, Old Testament, or even classical eras to that of the Venetian People.

In the last dome of the atrium mosaics the life of Moses is represented (figure 30), which completed this narrative of the Chosen People, and their existence and departure from Egypt. ${ }^{174}$ This dome remained largely intact until the late nineteenth century, when it was poorly restored, as was much of this cycle, when it was removed, cleaned, restored, and reapplied to the dome. The rich colors are much discolored by dirt, and much of the pink tesserae were lost in the process replaced by pink glazed white stone. This dome represents one of the strongest senses of a foreign and exotic eastern land, which is evoked through specifically Islamic architecture. ${ }^{175}$ The dome begins with The Abandoning and Finding of Moses; Moses meets the Pharaoh, and goes through the cycle of his life up to The Miracles of the Manna and the Quails (figure 31) and The Miracle of Water from the Rock. Interestingly, just as in the Abraham Cupola where the promise of Isaac was not fulfilled until the lunettes surrounding the dome, the Moses cupola is filled with the narrative of his time in Egypt while the lunette and apse above the north door contain the Crossing of the Red Sea and the miracles during the wandering of the Chosen People in the wilderness. The domes contain the narrative of the prophecy or God's promise, and lunettes represented the fulfillment of that promise, thereby stressing the fulfillment of the prophecy by isolating the fulfillment in such a manner.

Otto Demus contends that this narrative is focused on the life of Moses and not the Exodus of the Chosen People. This issue is never denied outright by Dale, although he relies

\footnotetext{
${ }^{174}$ Howard, 82.

${ }^{175}$ Howard, 82.
} 
heavily on the completion of the sojourn and Exodus of the Chosen People as an antitype or a model to the fate of the relics of St Mark. ${ }^{176}$ Demus considers the concept of a parallel between the fate of the Chosen People, into and out of Egypt, and the fate of St Mark as "going too far," and suggests a more conservative viewing which would draw a general connection between the Egyptian emphases as the land of St Mark. ${ }^{177}$ Despite the lack of scholarly debate between Dale and Demus on what the purpose of this dome is, it is definite that the inclusion of this narrative was intentional, and was included despite the fact that the model for the atrium, the Cotton Genesis, did not include the narrative of Moses. Thus, this was a specific completion of the mosaic cycle, chosen for the purposes of San Marco. Without the story of the Exodus of the Chosen People to the Promised Land, the parallel between Venice and the Hebrews, the ancient Chosen People of God would not have been complete. I intend to make it clear that certain iconographic references such as the themes of visions or predestination, as well as issues of visual connection as mentioned in the intersection of the translation, the Doge's custodianship of the relics, and the plight of the Chosen People, make it possible to draw the conclusion that the atrium mosaics were in fact drawing an intentional parallel with the fate of St Mark

The multiple narratives of St Mark act as a separate yet connected visual witness from the Old Testament mosaics of the atrium, to the shifting nature of self-imaging in this century. In indirect and unmistakable ways the basilica of San Marco mirrored the city's increasing selfconfidence and power, a process which can be specifically seen in the evolution of the Marcian legend within San Marco. The earliest mosaics through those of the twelfth century retell the Saint's legend and acknowledge his ties to the mainland city of Aquilea and Egyptian Alexandria,

\footnotetext{
${ }^{176}$ Dale, “Inventing a Sacred Past,” 96.

${ }^{177}$ Demus, The Mosaics of San Marco, v. 2, 98.
} 
whereas the thirteenth-century mosaics in the church recount episodes in the Saint's afterlife in a manner which cancels out all non-Venetian past. ${ }^{178}$

Despite Venetian accounts which suggest the inadvertent landing of merchant ships in the harbors of Alexandria, due to the Divine will of God, in truth the theft of Mark's relics was an intentional and political decision made due to the circumstances in the Adriatic region of the early ninth century. ${ }^{179}$ In 827 , Venice was attempting to maintain a maximum amount of independence from Carolingian Italy, the reach of the Pope, and the Byzantine Empire, while maintaining good relationships with both. At that time Charlemagne and his son had failed to gain political and military control over Venice, but had not given up hope of ecclesiastical control. At the Synod of Mantua, in 827, a blow was struck to Venice in which the right to ecclesiastical authority was awarded to Aquilea, due to the historical tradition of St Mark's mission to Aquilea and the sacred authority claimed because of this. Aquilea was at this time a province controlled by the Carolingians, thus putting Venice under the control of Charlemagne. Venetian reaction to the ecclesiastical arguments used in support of the political decision ultimately resulted in the determination to steal the body of St Mark. The most effective way to neutralize the decision was in the acquisition of the Body of St Mark, this allowed superiority by giving Venice a church in possession, thus chosen, by St Mark, versus one simply founded by him in the apostolic age. ${ }^{180}$

The role of relics within medieval communities was a unique and important one. To the medieval individual a relic was the host of sacred authority and had a life and will of its own. ${ }^{181}$ The relics of a saint could legitimize independent ecclesiastical authority, and the theft of relics was not considered theft, so much as the exercise of the divine and unquestionable intent of the

\footnotetext{
${ }^{178}$ McGregor, 34.

${ }^{179}$ Geary, 89.

180 Geary, 130.

${ }^{181}$ Geary, 4.
} 
saint. ${ }^{182}$ These relics could choose and affect their own fate as much or more then a living Saint could. What is of concern in this analysis of a medieval culture is not the actual history of the acquisition of St Mark's relics, but the portrayed history of his relics, specifically through the mosaics in San Marco, and the evolution of this myth to match the status and desires of Venice as it developed as a world power.

The mosaics of the Cappella di San Clemente, the translatio (figure 32, 33, 34, and 35), from the eleventh century, recount the translation of Mark's relics from Egypt to Venice after the mission and martyrdom of Mark. The Christian community of Alexandria had collected the relics after the martyrdom of Mark, and protected them until the city fell to the Saracens in 641, and the relics of Mark were once again in the hands of unbelievers. The account of the translation is recorded as follows from the Acta Santorum:

Through divine will the winds being favorable they did inadvertently what they would not have dared to do deliberately because of their respect for the Doge.. Whenever Venetians spent time in Alexandria it was their custom to offer daily prayers to St Mark... Because of this they were friendly with the priests who kept the shrine... the guardians of the shrine were distressed because they feared that the servants of the impious and evil prince of the Saracens would do to the shrine of St Mark what he had done to others... ${ }^{183}$

The pious men of Venice offered to take the priests and the relics to a worthier Christian home where they could be revered properly, and they cleverly hid the relics under a hamper of pork to deter the Saracens from examining the contents and due to the will and favor of the Saint were greeted with glorious odors from the relics which filled the city. The Venetians were

${ }^{182}$ Geary, 3.

${ }^{183}$ McGregor, 43-44. 
guided despite threats of storm and shipwreck quickly to Venice where the relics were greeted with great zeal and piety by the community. ${ }^{184}$

In these mosaics the evolution of the legend at this point is clear, it establishes the connection of sacred authority to Venice, as well as the piety of the Venetian people in the reception of his remains in contrast to the pagan environment from which they had been miraculously saved. This is a relationship between the will of St Mark and the holiness of the Venetian community which legitimizes the relic theft, and once again draws attention to the relationship between the Venetian sense of justice and the acquisition of the power of St Mark. This rendition of the translation is simple by medieval standards, a standard representation of the translation of a relic from an impious and undeserving environment to one worthier of the authority provided by the Saint. Despite exaggeration and representation of miraculous favor this narrative is relatively genuine to the course of events of the theft of the relics from Alexandria to Venice. ${ }^{185}$

In stark contrast to this quasi-historical narrative of the twelfth century are the narratives of St Mark from the second half of the thirteenth century, in the South Transept, and the Southwest Porch. Venice had reached a new pinnacle of political and economic power in the eastern Mediterranean at this time, thus they had outgrown the earlier legend of simple translation of the relics of St Mark. They were less interested now in the borrowed history of a local church, Venice revised its mythical history at this time to promote itself as a player on the world stage. ${ }^{186}$ The new pictorial narratives forge closer links with the evangelist, asserting Venice's destiny as "Chosen People" of Mark, guardian of his relics, and a predestined nation set within a universal history of the God's Chosen which reaches back to Creation. These new

\footnotetext{
${ }^{184}$ McGregor, 47.

${ }^{185}$ Geary, 88.

${ }^{186}$ Dale, "Inventing a Sacred Past," 100.
} 
myths not only supplied divine sanction for Mark's relics but more importantly for the exercise of power in his name, from the eleventh century on the relics came to justify both spiritual and temporal authority of the Doge.

Moving into the thirteenth century it is easy to see the contrast between the former, and more conservative mosaic of the translatio of Mark's relics, in the apparatio mosaics of the midthirteenth century (figure 36, 37). The two apparatio panels, located in the South Transept, summarize the legend; the first, the preghiera or prayer, depicts the clergy and citizens in prayer, showing a remarkably detailed view of the church. ${ }^{187}$ The second panel, the apparatio or apparition, depicts the breaking of the column and the revelation of the lost relics. ${ }^{188}$ This is a scene not connected to Saracen Alexandria or the translation of his relics to Venice, but a legend taking place within San Marco itself. This mosaic seems to have survived only in a curtailed form, being cut on various parts of the architecture and even the figures. ${ }^{189}$ This legend is a testament to the continued legitimacy of the possession of Mark's relics as well the piety and commitment of the Doge and Venetians to St Mark, highlighting the worthy nature of San Marco as home to this holy inheritance. ${ }^{190}$

The legend as written in the Acta Sanctorum asserts that after the burning of the earlier church of San Marco, and the construction of the new, the location of the relics died with the few individuals who knew where the were hidden. ${ }^{191}$ It is written in the Acta Sanctorum, that in 1094 after three days of fasting and prayer throughout all Venice "God heard their prayers and showed them the place, and suddenly a marble column split open and a chest containing his

\footnotetext{
${ }^{187}$ Demus, The Mosaics of San Marco, v. 2, 27.

${ }^{188}$ Demus, The Mosaics of San Marco, v. 2, 27.

${ }^{189}$ Demus, The Mosaics of San Marco, v. 2, 28.

${ }^{190}$ McGregor, 56.

${ }^{191}$ McGregor, 57.
} 
body which had been hidden within burst forth for all to see." 192 This revelation was followed by many miracles, all testifying to the power of St Mark's favor. In contrast to earlier myths, in the thirteenth century the Venetians assert the legitimacy of the continued possession of Mark's relics, justifying the current actions of Venice in its growing colonial power and conquest over the ancient city of Constantinople. This miracle confirms that Mark still deemed the actions of Venice worthy of his protection and authority, as they conquered in the name of the evangelist, this myth legitimized Venice as the site of Mark's living legacy. ${ }^{193}$

In the most critical elaboration of the saint's legend, in a narrative of the life of Saint Mark and most revealing about the thirteenth-century Venetian transformation, we see a narrative which firmly links the Saint with his final resting place, at the expense of all other ties to Aquilea, or previous Venetian ties to Byzantium or Rome. Located in what is now referred to as the Cappella Zen of San Marco, this area was once the South Vestibule of the church before the conversion in the early $16^{\text {th }}$ century to become the chapel of Cardinal Battista Zen. ${ }^{194}$ The purpose of this area is an important aspect when considering the intent of the thirteenth-century mosaics held within. It may seem now as if these mosaics are obscured in this chapel off the atrium, but when the thirteenth-century mosaics were installed this area was the south entrance to San Marco. This entrance faced the Piazetta, a highly trafficked main entrance, specifically used as a ceremonial entrance for important visitors to the city. ${ }^{195}$ Any mosaic placed in this area was not only widely seen but was of significant strategic importance. Aside from the façade mosaics these were the first images which created the visual experience of San Marco.

There are mosaics within the South Vestibule or Cappella Zen spanning many centuries prior to and after the thirteenth century. The earliest remaining mosaics are located in the apse-

\footnotetext{
${ }^{192}$ McGregor, 57.

${ }^{193}$ Dale, "Inventing a Sacred Past," 85.

${ }^{194}$ Demus, The Mosaics of San Marco, v. 1, 185.

${ }^{195}$ Demus, "Mosaics of San Marco" v. 1, 185.
} 
like niche above the door that leads into the atrium. These mosaics depict angels flanking the Virgin, although the Virgin is assumed to be a nineteenth-century replacement. ${ }^{196}$ The inscription surrounding this conch has been restored, the words are probably original and describe a contrast between Eve and the Virgin, which echoes the references in the Creation narrative. This is a typical Byzantine apse program, framed by a western Mariological idea, a combination which portrays a thoroughly Venetian tenor. ${ }^{197}$

Both the earlier twelfth-century and later thirteenth-century mosaics have experienced extensive and often poor restorations which have left them in poor disrepair, with uncertain originality. ${ }^{198}$ The images which are of concern to this paper are the thirteenth-century mosaics which are located in the barrel vault and depict the life of St Mark (figure 38). This thirteenthcentury addition leaves no trace of what decoration may have been in the vault previously. Prior to the installation of this narrative, the vault would have been decorated, and some have speculated that it was once a different cycle of the life of St. Mark which was altered to represent a more modern understanding of the Marcian legend. ${ }^{199}$ This version of the history of St Mark, his connection to Venice and the timing of its installation is very telling of the political climate after the conquest of Constantinople. This history redefined not only the Marcian legend, but the history and purpose of Venice itself in a way which nearly eliminated the importance of Aquilea in Mark's connection to Venice and replaced it with a divine predestination of the destiny of Venice and her people.

When analyzing this set of mosaics we must first acknowledge the extensive damage and restoration to this area of San Marco over the centuries and what this indicates about how these can be viewed and how reliable the images depicted are. Demus outlines the process of

\footnotetext{
${ }^{196}$ Demus, "The Mosaics of San Marco” v. 2, 40.

${ }^{197}$ Demus, "Mosaics of San Marco" v. 2, 41.

${ }^{198}$ Demus, "Mosaics of San Marco" v. 1, 186.

${ }^{199}$ Demus, "Mosaics of San Marco" v. 1, 186.
} 
restoration these mosaics have gone through in his extensive documentation on the subject. The most damage was done in the nineteenth century, including having survived multiple periods of being removed from the walls of the Cappella Zen and replaced later with extensive changes. ${ }^{200}$ Analysis of these processes has led Demus to assert that serious changes have been made to the style of these mosaics over the centuries and in many or even a majority of these mosaics the style of figures, faces, or whole scenes have been drastically changed. Despite the inconsistency with thirteenth-century style, it is possible to say, with certainty, that the iconographic and compositional scheme of the mosaics of the life of St. Mark are trust-worthy as representative of the original cycle of the life of St. Mark. ${ }^{201}$

The mosaics of the life of St. Mark are found in two parts, one on each side of a mosaic in the center of the barrel vault, the center is occupied by an image of Christ Emmanuel surrounded by geometric and vegetal ornament. ${ }^{202}$ In each of the two halves of the barrel vault there are six scenes of the life of St. Mark arranged in two tiers. The cycle begins in the upper northeast corner of the vault and ends in the lower northwest corner. In the first set of the cycle, in the east half of the vault, in the upper tier there are the scenes of Mark Writing the Gospel, Mark Presents the Gospel to Peter, and Mark Baptizing in Aquilea. In the lower tier are the scenes of Mark's Dream Vision of the Venetian Lagoon or the predestinatio (figure 39), where a very specific inscription reads "While he was sailing across the area where the church of San Marco now stands, an angel announced that at a certain time after its death, his body would be interred here with great honor." ${ }^{203}$ Also in the lower tier are the scenes Peter Consecrates Hermagoras, and Mark heals a Demoniac. In the west half of the vault, in the upper tier we find scenes of Mark Ordered by a Dream Vision to Go to Alexandria, Mark's Voyage to Alexandria, and Mark. Heals Anianus. Finally, in

\footnotetext{
${ }^{200}$ Demus, "Mosaics of San Marco" v. 1, 184

${ }^{201}$ Demus, "Mosaics of San Marco" v.1, 185.

${ }^{202}$ Demus, "Mosaics of San Marco" v.2, 185.

${ }^{203}$ Dale, "Inventing a Sacred Past," 97.
} 
the lower tier we see the scenes of Mark Strangled at the Altar, Mark Dragged and Killed, and the Burial of Mark. ${ }^{204}$

In the thirteenth-century images of the life of St Mark, there is a near omission of all Aquilean reference, the only remnant of Aquilea's role in St Mark's history is a scene of a generic baptism. Only elements that assert the importance of St Mark, such as his miracles, his connection to St Peter and his gospel authorship remain, all details that might allocate some of St Mark's authority elsewhere are omitted. The most important aspect of this mosaic is the addition of the predestinatio scene to the legend of the evangelist. This is the first image of this element of the legend of St Mark, and it is installed near the time of the first known written documentation from Martino da Canal's Estoires from 1265. The following is an excerpt which explains in full the contents of this narrative:

There is a legend of many centuries duration handed down by the original inhabitants of the Lagoon of an incident which occurred during the travels of St Mark.... The evangelist found the surface of the sea covered with large waves and so he chose to travel though the marshes... In the quiet of the night a smiling angel appeared to him and said "Do you not know where you are? For much longer than you imagine this will be your resting place." Mark misunderstood the angel's words, thinking they warned of a shipwreck, but the angel continued, "be of good cheer you are not destined for an obscure death, but after long labors the Prince for whose honor you struggle will award you the crown of martyrdom. This place which is now so humble and bare will one day be more welcome to you then any other. Know one day a temple will be here where you bones, stolen away from

${ }^{204}$ Demus, “Mosaics of San Marco” v.2, 186. 
the barbarians will find perpetual rest. Through your intercession and your power the piety and virtue of this nation will make it great. ${ }^{205}$

This mosaic illustrates the scene showing a small open boat, tied to a mud bank, from which Venice would grow. Mark sits with a saintly companion, as well as a figure that is awake and without a nimbus serving as a witness to the miracle. ${ }^{206}$ The story told by this image is very different from the translation narrative, there the aim was to establish Mark as an apostle and show the miraculous and favorable circumstances of his translation from Egypt to Venice, whereas, in the Cappella Zen the mosaic assigns the saint a new role as city founder. Through Mark's influence and power, coupled with the virtues of the people of the Lagoon, this mud bank would become a great nation. This narrative not only transforms Mark from apostle to city founder, but redefines the community and its political leadership as a pious and predestined nation that, through spiritual dedication and the blessing of St Mark, was intended by God to become a powerful Empire in the Christian world.

The story of St. Mark is continued on the façade in the story of the translation of his relics, scenes that are a sort of "title page," as Demus terms it, that show the close relationship between the legend of the relics of St. Mark and the claim of the church as based on the ownership of the relics. ${ }^{207}$ In contrast to these façade mosaics, the Life of St Mark inside the Cappella Zen represents amplification, or a more complex commentary, in which the motif of the relics and Venetian divine right to their possession occupied the second visual representation seen by the viewer. This myth of predestination originated in the first half of the thirteenth century, just decades prior to its installment in San Marco, an era which brings up compelling questions about how this change in the legend of St Mark and his relationship to Venice

\footnotetext{
${ }^{205}$ McGregor, 61.

${ }^{206}$ McGregor, 61.

207 Demus, “Mosaics of San Marco” v.2, 187.
} 
corresponds to aspects of Venetian culture in the thirteenth century, such as cultural independence from Byzantium. ${ }^{208} \mathrm{~A}$ time which Demus refers to as the "early Christian renascence of thirteenth-century Venice," after acquisition of so many Byzantine and Early Christian relics, artists of Venice had ample opportunity to cultivate a talent for imitating an Early Christian style which was conducive to the desire to connect Venice with an ancient destiny as a "Chosen People" and part of a continuous Christian history. ${ }^{209}$ There are many examples of medieval translation of relics, and there are many instances of medieval copying but none have the same attitude as seen here in Venice where they are so drastically shaping their communal and historical identity, even "fak[ing] a past" which would legitimize both their church and their temporal power. ${ }^{210}$

There is no longer reliance within these images on Mark's history in Aquilea as first Bishop, only a reference in order to establish location, nor is his prominence in Grado an important part of the narrative. ${ }^{211}$ This scene makes visual connections of a divine path which led Mark past the Venetian Lagoon by boat, and includes important elements such as his connection with the Gospel, St Peter, his miracles which mark him as holy, and his death in Alexandria. ${ }^{212}$ In this predestined resting place his relics would await their exodus to the land of the Venetians, to the new "Chosen People". ${ }^{213}$ Venice is being shown as an heir to Alexandria before Mark reached Egypt, something which is emphasized through the Egyptian Motif in the north wing of the Atrium, and is continued in the later work of the Silver Paliotto in which all Aquilean scenes are completely eliminated. ${ }^{214}$ This progression of historical change is indicative of how visual history is not shackled to documented history, but how independent pictorial

${ }^{208}$ Debra Pincus, The Tombs of the Doges of Venice. (Cambridge, UK: Cambridge UP, 2000), 12.

${ }^{209}$ Demus, "A Renascence of Early Christian Art,” 348.

${ }^{210}$ Demus, “A Renascence of Early Christian Art,” 353.

${ }^{211}$ Demus, "Mosaics of San Marco" v.2, 189.

${ }^{212}$ Demus, "Mosaics of San Marco" v.2, 187.

${ }^{213}$ Dale, "Inventing a Sacred Past," 90.

${ }^{214}$ Demus, "Mosaics of San Marco” v.2, 188. 
inventions can constitute independent arguments and proof to the viewer. ${ }^{215}$ According to many scholars this era of the thirteenth century was a time when all previous claims to the relics or legacy of Mark was eradicated, by claiming a divine destiny for Mark in Venice, thus making the power of Venice a predestined inheritance. ${ }^{216}$

As witnessed by the atrium mosaics of this period, the designers behind these mosaics were reaching to a far more ancient past in their use of archaic style, an early Christian model, and even reoccurring themes of vision, destiny, and Egypt as the home of St. Mark. ${ }^{217}$ The use of contemporary themes from Byzantium was abandoned in favor of this renaissance of early Christian style and models, which coincides with the era of reshaping Venetian history as a narrative beginning in the early Christian era. Venice revisited its mythical history to promote itself as a player on the world stage as it pertains to their sacred history, just as they had asserted themselves in this century as a commercial and cultural power.

In this reinvention of the Marcian legend and its connections to Venice, there was an attempt to portray the Venetians as the "Chosen People" of Mark in many aspects of the thirteenth-century mosaics. ${ }^{218}$ This represents a new era on a continuum of change and reinvention of self-identity in Venice, which began at foundation, in which Venetians have elaborated images of the city's distinctive origins and "special place" in history. ${ }^{219}$ This created not a single myth but a layered and changing identity which changed along with social or political needs. ${ }^{220}$ This was an opportune time for Venice to recreate its mythical origins due to the great change in the era of the thirteenth century, as Venice was transformed into an imperial power at

\footnotetext{
215 Dale, “Inventing a Sacred Past,” 105.

${ }^{216}$ McGregor, 34.

${ }^{217}$ Demus, "Renascence of Early Christian Art," 96.

${ }^{218}$ Dale, "Inventing a Sacred Past," 85.

${ }^{219}$ James S. Grubb, "When Myths Lose Power: Four Decades of Venetian Historiography." The Journal of Modern History 58.1 (1986), 43.

${ }^{220}$ Grubb, "When Myths Lose Power," 43
} 
the expense of Byzantium. ${ }^{221}$ Over time, the importance of Mark's blessing over the translation of his relics grew, and this culminated in the expansion to the representation of Mark's preVenetian career in the Cappella Zen.

Aside from the aspects discussed concerning this appearance of the predestinatio legend and its importance in the thirteenth-century climate. There remain issues such as the importance of the Doge's gain by asserting, as fact, Mark's presence in Venice as a matter of God's, not simply modern Venetian ambition, but ancient prophecy. These mosaics which show the divine revelation to Mark of his eternal rest in Venice also show a dream-vision of his destiny to go to Alexandria, where he would be martyred. He was meant to go on a mission to Egypt, yet he was also destined to be brought out of this pagan land to a new "Promised Land" in Venice. ${ }^{222}$ There is not only an ideological link between Mark and the Chosen People, but a physical connection within San Marco as well. There is a natural line between the Cappella Zen mosaics of the barrel vault where the Venetian people have been chosen by God, and the Old Testament narrative of the Chosen People in the atrium, in fact a narrative which received uncommon attention in San Marco. ${ }^{223}$ This imagery and its connection with the Old Testament narrative is not a legend which would have been easily dismissed but an argument placed in the most prominent location in all of Venice, an argument which augments the role of Venice from a successful and wealthy merchant republic to a nation, although lacking ancient historical roots, that was predestined to hold and usurp the role as God's chosen nation and people.

This transformation from borrowing the sacred heritage of a local town, or the cultural tradition of a Christian Empire to laying a divine claim to the heritage and power relates to the power of both Venice and the Doge in many complex ways. This aspect brings attention to the

\footnotetext{
${ }^{221}$ Georgopoulou, Maria. 479.

${ }^{222}$ Dale, "Inventing a Sacred Past," 89.

${ }^{223}$ Dale, "Inventing a Sacred Past," 90.
} 
fact that all things the Venetians, and specifically the Venetian government, did were done in the name of St Mark and their power was thoroughly invested there. It was in Mark's name that the Doge himself waged war and governed Venice. ${ }^{224}$ At this time in the thirteenth century the ducal presence at San Marco became more pronounced visually and legally, as the power of the Republic of Venice grew on the world stage, a change which called for an expansion of the visual legend of Venice within the Church, which was expressed in the atrium and in the predestinatio legend. ${ }^{225}$

As the prominence of San Marco grew as a center for politics, religion, and culture, so too did the history and theology change to suit the image the desired image of the Doge and Venice. ${ }^{226}$ What was happening in this era was not only a strengthening bond between the image of the Doge and San Marco, but a bond which committed to social memory the connections between St Mark, his relics, Venice, the Doge, and his divine right to rule. ${ }^{227}$ The era of the installation of the Life of St Mark was an era that is characterized by Debra Pincus not as one of many periods of mythogenesis, but as the defining period of mythogenesis when Venice departed from using the images and myths of other states and began creating their own. ${ }^{228}$ It was a time of transformation from the "favored daughter" of Byzantium to a world power in which these mosaics were used to mold a myth to appropriate a sacred and ancient past in an empire that was relatively young by medieval standards. ${ }^{229}$ In an era when a sacred past had the power to legitimize current civic institutions such as the Republic or even the seat of the Doge, it was imperative to hold these sacred relics, and in the thirteenth century, to make claim to the relics as

\footnotetext{
${ }^{224}$ Dale, “Inventing a Sacred Past,” 93.

225 Pincus, "Tombs of the Doges of Venice," 11.

226 Sinding-Larsen, Christ in the Council Hall. Studies in the Religious Iconography of the Venetians. (Rome: 1974), 182.

227 Sinding-Larsen, “Christ in the Council Hall,” 183.

${ }^{228}$ Pincus, "Venice and the Two Romes," 104.

${ }^{229}$ Georgopoulou, 491.
} 
a sign of Venice as a destined Christian Empire, and part of a holy narrative which to the medieval beholder was still alive. ${ }^{230}$

In analyzing the mosaics of the thirteenth century it is impossible to avoid the fact that there is a shift in the content, style, and iconographical choices in this century as well as consistent themes which are indicative of the changing political desires within the Venetian Republic century. Thus, in order to accurately analyze this artistic shift it is necessary to also take into account the general political situations surrounding the change that is visually present in San Marco in this era. In the events of the twelfth century, including the rift with Byzantium in 1171, the Peace of Venice in 1177, and shifting approaches to Venetian history, elements of thirteenthcentury politics and thought were set in motion. In a sense, this set the stage for the more drastic events and changes witnessed in the chronicles, monuments and political action of the thirteenth century.

Beginning in the twelfth but solidified in the thirteenth century this state was transformed from a Merchant Republic to a Maritime Empire which was in control of threeeighths of Byzantium, a "mother," in a sense, to this republic and an empire which it had so long emulated and drawn from culturally. ${ }^{231}$ Many aspects of the Venetian state were in transition in this period from relationship with the Papacy, the role of the Doge within the commune, economic and political relationship with Byzantium and other world powers, and the shape of the Venetian myth of origin. It is thus important to not only analyze the changing imagery within San Marco but to look at how and why the self-image of Venice was changing in this period, as well as how these visual narratives are mirrored in contemporary documents and chronicles.

${ }^{230}$ Dale, Thomas A. "Stolen Property: St Mark's First Venetian Tomb and the Politics of Communal Memory." Memory and the Medieval Tomb. Ed. Elizabeth Valdez El Alamo and Carol Stamatis Pendergast. (Aldershot, UK and Brookfield, VT: Ashgate, 2001), 205.

231 Thomas F. Madden, "Venice, the Papacy, and the Crusades before 1204," in The Medieval Crusade, Susan J. Ridyard, ed. (Woodbridge: Boydell Press, 2004), 117. 
As discussed the previously, we place stock in the images of San Marco and how they reflect societal trends, values, and changes not simply because the images have been preserved but because Venetians also put stock in what images were constructed or changed. These were not merely reflections of events in the Mediterranean world but important demonstrations and documents in themselves which could be referred to as Venice molded its own contemporary and ancient history. The events of the eleventh century were significant, including the molding of the Venetian myth through the Origo, a historical chronicle, or the growth of the Venetian building and consolidation of her trading empire by establishing permanent Venetian colonies on the islands throughout the Aegean, it was the events of the thirteenth century that led to the new relationship with Venetian image, antiquity, and the Mediterranean world. ${ }^{232}$ For instance, the myths created in the Origo were further developed and monumentalized in the thirteenth century in a manner that confirmed the Venetian self-identity, and the colonies in the Aegean would serve as outposts for the more rapid expansion following the territorial gains made after the Fourth Crusade and the conquest of Constantinople of $1204 .{ }^{233}$ As Venice grew into an imperial power her ruling class continued to refine an already impressive civic image and her chroniclers would revise the historical record many times over, in order to reflect a growing desire to deepen Venetian roots to reflect a sense of destined greatness for the republic.

Another factor which affected the thirteenth-century climate took place in 1171, when the relationship which had nourished Venetian success was changed, which may have helped lead into this reevaluation of Venetian self-imaging. In 1171 the roots of Venetian government were shaken when Constantinople turned against its longtime ally in favor of Venetian enemies, mainly Genoa, Pisa, and Amalfi, by allowing them trading privileges. These privileges had once only been allotted to the Venetians, but the favor of the Emperor was revoked after he was

\footnotetext{
${ }^{232}$ Patricia Fortini-Brown, Venice and Antiquity. (New Haven \& London: Yale UP, 1996), 12.

${ }^{233}$ Fortini-Brown, Venice and Antiquity, 12.
} 
angered by an insult from a group of Venetians mocking his dark skin. ${ }^{234}$ The Byzantine

Emperor, offended due to this personal insult proceeded to lay blame on the Venetians for an attack on the Genoan settlement within the city and seized all Venetian residents of Constantinople as well as their possessions. After this mistreatment of Venetians, the relations deteriorated further between Constantinople and Venice as an envoy, including the Doge, was invited into a trap in Constantinople, resulting in a massacre and murder of the Doge. After these events of 1171-1172, the fight against the Byzantines, the loss of economic favor, and finally the murder of the Doge there was a rapid increase in the power of the commune within the government. ${ }^{235}$ This is pertinent to the understanding of the thirteenth century as it gives context to the rise of the commune in the thirteenth century as well as the lingering importance of the Doge, a sign of the Venetian people, despite waning power. Most importantly this marks the early signs of departure from the former Venetian attitude towards Byzantium which was characterized by subordination of other political goals in favor of maintaining the special relationship with Byzantium. ${ }^{236}$ This uneasiness may have manifested itself in the willingness of Venice to break this traditional tie to Byzantium in the events of $1204 .^{237}$

Another element which began in this time of turmoil and violence between Byzantium and Venice was the growing power of the commune at the expense of the Doge, and in a sense of the citizens of Venice as well. The commune was formed under Doge Pietro Polani (11301148), temporarily and was never disbanded; this formed a new sphere of power between the Doge and the people which would continually gain more power throughout the thirteenth

\footnotetext{
${ }^{234}$ Christopher Hibbert, Venice: the Biography of a City. ( New York \& London: W.W. Norton and Company, 1989), 18.

${ }^{235}$ Madden, "Venice, the Papacy, and the Crusades before 1204," 95.

${ }^{236}$ Frederic C. Lane, Venice: a Maritime Republic. (Baltimore and London: The Johns Hopkins UP, 1973), 42.

${ }^{237}$ Lane, Venice: a Maritime Republic, 38.
} 
century. ${ }^{238}$ This ruling class bordered on nobility, although it lacked the consistency due to the fluid nature of Venetian power as based on commercial success, not mere blood line. This great increase in power began after the 1171-1172 events after Doge Vitale Michiel II went against the will of the commune in his actions by traveling to Constantinople. The ensuing disasters made it possible for the commune to remove the Doge's right to contradict the commune, as well as making it illegal to elect a Doge who would work against the expansion of the commune's power. $^{239}$

After this point the Great Council held the power to appoint all the ministers of the government and also the representatives of the Council, thus becoming a self-perpetuating oligarchy. ${ }^{240}$ In this period increases are seen in offices such as that of the procurator as well as the formation of new governing counsels such as the Quarantia, or counsel of forty. ${ }^{241}$ Formerly the power of the Doge was invested in the people, or popular assembly and the barrier now between those changed the once unchallenged power of the Doge. ${ }^{242}$ The phrase to introduce the elected Doge in this period is significant, "Here is your Doge, if he please you." ${ }^{243}$ Although this usurping of power did not mean the role of the Doge is downplayed in Venetian society, in fact as the governing power of the Doge decreased, the pomp and symbolism behind the ceremonies representing his power increased. ${ }^{244}$ Thus the imagery in San Marco, as a church of the Doge, gained potency as the image of the Doge as a symbol of Venice was bolstered even as the range of his power narrowed.

This study of the role of the Doge and increasing powers of councils or positions may seem obscure when studying the role of the mosaics of the thirteenth century, but the figures of

\footnotetext{
${ }^{238}$ Madden, "Venice, the Papacy, and the Crusades before 1204," 94.

239 Madden, "Venice, the Papacy, and the Crusades before 1204," 95.

${ }^{240}$ Hibbert, Biography of a City, 20.

${ }^{241}$ Hibbert, Biography of a City, 20.

242 Madden, "Venice, the Papacy, and the Crusades before 1204,” 93.

243 Hibbert, Biography of a City, 20.

${ }^{244}$ Fortini Brown, "Self-Definition of Venetian Republic," 523.
} 
the procurator and the Doge play enormous roles in the administration and meaning of San Marco. The importance of the Doge is embodied in this structure both directly and indirectly. The Doge is the protector of Mark's relics and it is from the relics that he draws his power, the role of a wise and just ruler is emphasized in at least three of the domes. Although this power is waning it is of utmost symbolic importance as a reminder of the foundation of Venice on the premise of rule by the people through the figurehead of the Doge. In fact, the virtues presented by Joseph may be seen as a guide to the Doge, of the just and wise hand of the ruler as a provider and protector of his people, specifically in times of scarce resource. The concept of stability was of great importance to Venice and the figure of the Doge, even amongst power struggles, was maintained for the benefit of stability. Despite the fading reality of this principle, it had moral importance in the city, in fact the predestinatio legend in conjunction with the Old Testament mosaics based on early Christian models are attempts to visually deepen Venetian history thereby strengthening the claim to the predestined power of the republic, further legitimizing the role of the Doge.

As the power of the Doge dwindled, the importance of other offices increased significantly including that of the Procurator of San Marco. The earliest evidence for the existence of the Procurator comes from the twelfth century, but there is speculation that the office went back as far as the acquisition of Mark's relics. ${ }^{245}$ Initially this post was a much narrower position which consisted of delegating the responsibilities of administering the church, a sort of vicar and caretaker of the church. However the responsibilities expanded as rents and tithes paid to the church led to substantial financial holdings. ${ }^{246}$ This progression was most acute in the first half of the thirteenth century, as the importance and number of the procurators grew

\footnotetext{
${ }^{245}$ Reinhold C. Mueller, "The Procurators of San Marco in Thirteenth and Fourteenth Centuries: a Study of the Office as a Financial and Trust Institution." Studi Veneziani XIII. Ed. Leo S. Olschki. (Venice: Firenze, 1971), 108.

${ }^{246}$ Mueller, “The Procurators of San Marco in Thirteenth and Fourteenth Centuries,” 109.
} 
substantially and finally the Great Counsel took over the right to elect the procurator as well as choose the number which by 1269-1260 had gone from one to four since the beginning of the century. ${ }^{247}$ At this point the office of the procurator was of utmost importance and prestige, second only to the Doge, as witnessed by Andrea Dandolo's position as procurator previous to his election as the Doge.

The eventual role of the procurator, in the thirteenth century, evolved into a financial and trust institution; they administered to the church, but also dealt in the administration of wills, inheritance, the fate of orphans, and many roles which embody the fine line in Venice between private and public institutions. This city was built of fluid wealth and status, on commercial success as a means for political might, to such an extent that public and private wealth were inseparable as the public good depended on the presence and fair administration of private wealth, a fact which is displayed by the evolution of the office of the procurator. ${ }^{248}$ This growth in the strength of the procurator, a position which drew its importance from San Marco, and thus the religious power drawn from St Mark, is important when considering the thirteenthcentury mosaics as it illustrates the power housed within this sepulchral chapel. The procurator drew his power directly from St Mark, and as the power and even the designer behind the shape of the mosaics it is easy to understand why such a politician would wish to extend the legend of St Mark to match the growth of both Venice and the office of the procurator. This growing power of the procurator witnesses the importance of the legend and history of St Mark, as such, it illuminates how this unique Italian merchant republic came to fashion its history outside of the typical avenues of Roman foundation, relying instead on the history and destiny of its patron saint and the intangible will of God.

\footnotetext{
${ }^{247}$ Mueller, “The Procurators of San Marco in Thirteenth and Fourteenth Centuries,” 109.

${ }^{248}$ Mueller, "The Procurators of San Marco in Thirteenth and Fourteenth Centuries," 220.
} 
Further in the investigation of the late twelfth century and its effects on Venice are the events of 1177 and the Peace of Venice, an event which was of enormous importance for the increasingly self-confident Venetians as well as a cornerstone of the evolving myth of Venice. ${ }^{249}$ In this period Venice played a major role in the in the mediation between Frederick Barbarossa and Pope Alexander III. The Venetians under Doge Domenico Morisini were anxious to avoid unneeded conflict, but with the advent to the imperial throne in the West of the young, ambitious Frederick I of Hohenstaufen, nicknamed Barbarossa, the situation was transformed. Barbarossa announced his intention to restore imperial Rome to its former grandeur, and marched into Italy, reducing to submission Italian states which had defied him. Afraid of losing her coveted independence, Venice joined the fight at the defense of Rome and Pope Alexander III alone with the Greater Lombard League. ${ }^{250}$ The murder of the Doge in 1172 was a set back, and after the installation of Doge Sebastiano Ziani he immediately put his hand to repair the damage done in these foreign ventures. ${ }^{251}$ He made peace with Norman Sicily, as well as with the Byzantine Emperor, and when it came time to negotiate peace between Barbarossa and the Pope, Venice was selected to hold the momentous negotiations.

This serves to illustrate the twelfth-century Venetian relationship with the Papacy, which further attests to the changes in Venetian allegiances and identity in the thirteenth century. It is often assumed that Venice, with its strong connections to the Byzantine Empire had consistently poor relations with Rome, when in truth prior to 1204 the relations were very good between Venice and Rome, the Doge and the Pope. ${ }^{252}$ As described, in the conflict of 1177 between Pope Alexander III and Frederick Barbarossa, Venice came to the defense of the Pope resulting in the Peace of Venice. For obvious reasons this resulted in a very good standing with the

\footnotetext{
249 Madden, "Venice, the Papacy, and the Crusades before 1204,” xvii

${ }^{250}$ Hibbert, Biography of a City, 23.

251 Hibbert, Biography of a City, 22.

252 Mueller, "The Procurators of San Marco in Thirteenth and Fourteenth Centuries," 96.
} 
Papacy. In conflicts concerning the lack of Venetian participation in the crusades Venice craftily defended her actions, pointing to the willing participation in the ban against trading with Islamic countries, resulting in a loss of a lucrative business relationship to Venice. Venice saw this as its own service to the crusades, and thus in 1187 had this restriction lifted allowing trade with Egypt in exchange for funds and manpower for the Fourth Crusade. ${ }^{253}$

The Fourth Crusade became the breaking point between Venice and Rome, although dealings were positive through the preparatory years up to 1201, they became strained as the Pope began to fear Doge Enrico Dandolo would take advantage of the arms and man power at his disposal. The elderly, blind Dandolo was not solely leading the Crusade but was working at the behest of the Pope and in conjunction with the French, led under Geoffrey Villehardouin. However, after time the Venetian Doge acquired significant power over the fate of the Crusade due to the substantial loan given the French, which they required in order to begin the campaign. ${ }^{254}$ With the financial status of the leaders to whom he had loaned the money, it was doubtful this large debt of 34,000 marks would be returned, or that the Venetians could hope that the booty from this Crusade would be able to make up such a debt, based on the financial failure of the Third Crusade. Doge Dandolo then proposed that the payment of the crusaders' debt be deferred, if they helped him subdue Zara, a nearby city. Zara was engaged in one of its innumerable efforts to assert its independence from Venice and become a rival power to Venice. $^{255}$

The region of Zara had come under the protection of Emeric of Hungary's control, a fellow crusader, thus the Pope issued a warning to stay away from his lands, a warning the Venetians and their crusaders ignored. This decision crumbled the formerly benevolent relations

\footnotetext{
${ }^{253}$ Madden, "Venice, the Papacy, and the Crusades before 1204,” 86.

${ }^{254}$ Lane, Venice: a Maritime Republic, 37.

${ }^{255}$ Lane, Venice: a Maritime Republic, 37.
} 
between Venice and Rome. ${ }^{256}$ After a successful campaign in Zara, a second diversion of the Crusade from the Holy Land was agreed upon. ${ }^{257}$ The decision to divert to Constantinople was again clearly in accord with Venetian interests, it was decided to proceed to Constantinople and place on the Byzantine throne a claimant called "young Alexius," the favor of the Western knights was won by promises by Alexius to bring Byzantium back into submission to the papacy, and even contribute funds and soldiers to the crusader cause. ${ }^{258}$ This only solidified the crisis with the Pope in Rome and was seen not as a choice to support the Crusade but a sign of Dandolo's greed, at which point all Venetians were excommunicated by the Pope. ${ }^{259}$

Aside from the issue of Papal relations, the events of 1204 and the implications for Venice were enormous, and in many ways underlie many if not most of the artistic and historiographic changes in the thirteenth century. When the Crusade set off in November 1202 from Venice, they were all bearing the emblem of St Mark under the flying banner of the apostle and patron saint. ${ }^{260}$ Both victories at Zara and Constantinople were won under the flag of Mark and were attributed to his favor upon Venetian actions. The victory at Constantinople was especially memorable as it is reportedly the actions of the Doge, under his banner of St Mark that turned the tides in both July 1203 and April 1204. ${ }^{261}$ The first assault set Alexius upon the throne, and the second led to the victory over the city.

After the Crusaders achieved their initial goal in July of 1203, it became apparent that Alexius' promises of payment were not going to be fulfilled, and after a time of waiting and sporadic violence the crusaders decided to take what they were owed in the beginning of 1204 . In three days the booty collected amounted to 400,000 marks and 10,000 suits of armor as well

\footnotetext{
${ }^{256}$ Madden, "Venice, the Papacy, and the Crusades before 1204,” 94.

${ }^{257}$ Lane, Venice: a Maritime Republic, 37.

${ }^{258}$ Lane, Venice: a Maritime Republic, 38.

${ }^{259}$ Madden, "Venice, Papacy, and the Crusades," 94.

${ }^{260}$ Hibbert, Biography of a City, 27.

${ }^{261}$ Lane, Venice: a Maritime Republic, 41.
} 
as sacred relics. ${ }^{262}$ The new imperial constitution allotted a council of twelve members, six Venetians and six barons, to elect an Eastern emperor; the position was offered and wisely refused by the aging Dandolo. The Venetians experienced a favorable outcome and once more experienced a special position with Byzantium, the Doge was free of allegiance or oath to the Emperor, Venice was assured all her spoils, and that all nations that stood against Venice would be banned from the Empire. ${ }^{263}$ Finally, Venice was awarded three-eights of Constantinople and was allowed to purchase the island of Crete, which was of considerable strategic importance. ${ }^{264}$ Venice acquired the fabulous wealth, rich artistic heritage, and relics they had for so long revered from Constantinople, and eventually the title for their Doge of "Lord of one quarter and a half of Byzantium.",265

Although this is merely a brief glimpse of the developments which led to the political environment of the thirteenth century in which Venice achieved a "quantum leap" in power and wealth, it sets the scene for what the Venetian world had become in the time of the mosaics in question. ${ }^{266}$ Despite Venetian attempts to deepen it roots within history in the eleventh and twelfth century to suggest pre-Roman roots in histories such as the Origo, it was never a wholly separate entity from Byzantium throughout the years as it emulated the culture and appropriated the history of the Christian empire, or other provinces such as Aquilea. The conquest of Constantinople seems to have contributed many factors which changed the fabric of Venetian culture, such as the great wealth taken in spoils, the historical and sacred artifacts, enhanced power in the form of strengthened colonies as well as control over three eights of the Empire. Also of importance was the symbolic affirmation provided by Venetian control over the empire

${ }^{262}$ Lane, Venice: a Maritime Republic, 41.

${ }^{263}$ Lane, Venice: a Maritime Republic, 42.

${ }^{264}$ Lane, Venice: a Maritime Republic, 43.

${ }^{265}$ Thomas F. Madden, Enrico Dandolo and the Rise of Venice. (Baltimore \& London: The Johns Hopkins UP, 2003), 200.

${ }^{266}$ T.S. Brown,"History as Myth: Medieval Perceptions of Venice's Roman and Byzantine Past." The Making of Byzantine History. Ed. Roderick Beaton and Charlotte Roueche. (London: Variorum, 1993), 145. 
whose images and institutions Venice had drawn on for political and historical legitimacy prior to the thirteenth century. As a result, the approach to Venice's self-fashioning in texts and monuments changed to fit the new status as the conqueror of Byzantium, and a new world power.

It is interesting when examining this Venetian desire to refashion history to examine the overall benefit to Venice of controlling a great portion of Byzantium. After the great wealth the sack of Constantinople brought to Venice initially, the lordship over this once proud capital was not merely a wise financial decision for this new maritime empire. During the majority of the control over this territory Venetians were not making a substantial profit and Venetians were heavily burdened in their efforts to protect the city from other enemies. ${ }^{267}$ The population also declined from its height under the Comneni dynasty of 400,000 to approximately 40,000. Thus, in this time real estate prices plummeted while Venetians were faced with being sole protectors of the capital. ${ }^{268}$ This raises the question of what Venice was benefiting from this title if not wealth, especially in a Republic that was defined by commercial success. Venice valued holding the power and prestige associated with the less ancient but highly pious eastern capital that was the embodiment of an ancient Christian Empire, the land from which Venice had at times been ruled and even after independence the empire from which Venice drew its models and images of historical legitimacy. This republic was based on myths of being the oldest independent Italian state, and on principles of antiquity and freedom, both of which were further enhanced by fulfilling what was seen as the will of St Mark, as well as the supposed prophecy of Constantine

${ }^{267}$ Louise Buenger Robbert,"Rialto Businessmen and Constantinople, 1204-1261." Dumbarton Oaks Papers 49 (1995), 44-46.

${ }^{268}$ Robbert, "Rialto Businessmen and Constantinople,” 53. 
that Byzantium was destined to fall to Venice, and Venice was divinely intended to rise as the next Christian empire. ${ }^{269}$

This outline of the thirteenth-century state of affairs in Venice may be summed up in a few assertions. Most importantly, going into and throughout the thirteenth century, Venice was a growing commercial and maritime power. Throughout the century the commercial strength of Venice grew through the entire Mediterranean world and Venice solidified its positions by gaining monopolies on commodities such as salt or the establishment of Venice as the "staple" of the Adriatic where goods had to be brought, taxed and sold, as well as control over regions such as Dalmatia, Crete, and Apulia. Important in this century was the reassertion of control, as in the case of the revolt led by Zara in 1243 which led to defeat by Venice, of not only Zara but the Genoans and Pisans as well. Also consistent in Venice in the thirteenth century was the weakening power of the Doge in favor of a growing and strengthening ruling class, as well as the increase in the symbolic importance of the Doge as a representative of Venice. Yet even as power grew, connections weakened, Byzantium was no more, and the favor of the Papacy had been shattered. This increasingly influential nation was attempting to stand on its own, without any sanction from Byzantium or Rome, creating a need for a form of independent sanction. It is this need that I contend is filled by the myths and images of the thirteenth-century, myths that transformed the success of Venice into fulfillment of ancient prophecy and the will of God.

Another imperative aspect of thirteenth-century Venice is set less in governmental affairs, although it is inspired by them: the Venetian self-identity. Although Venice is not alone in attempts to redefine her past, Venetian historians and mythmakers were not faced with a simple redefinition of the past as in other Italian cities, but with building up an elaborate legend of Venice's origins from a past which was shallower then most Italian cities. This aspect in

${ }^{269}$ De Vivo, “Justifications of Venetian Power,” 159. 
Venice was believed by the Venetians to be the key to the success of their city. ${ }^{270}$ It is reasonable to assume that the Venetians harbored this "obsession" with their past because the whole medieval world inherited this idea that the essence of a society's present and its later greatness lay in stages of early development. ${ }^{271}$ In Venice, in chronicles as well as pictorial narratives of the thirteenth century, it would seem that in a uniquely Venetian way, its present or future greatness lies not only in the myth of its development but also in the myth of its pre-development or destiny to exist as a mighty, independent, Christian empire.

There are limited sources on Venetian history, as is noted by many scholars, yet what is known is that this city was not of Roman foundation and was not largely inhabited until after 568 when surrounding towns fled from Lombard invaders. For the next 150 years Venetia was a poor component of the Byzantine Empire, along with Ravenna, Rome and Naples. ${ }^{272}$ In contrast to the "real history" of Venice, by the eve of the thirteenth century many complex myths of origin had developed and overlapped, including myths of foundation by Attila the Hun in the fifth century as well as the myth of foundation by the Trojans in the fifth century BC. ${ }^{273}$ These myths were varied and exhibit "the method of adapting suggestions that avoid declarations that are too explicit which is characteristic for Venice in its ideological attitude." 274

Before discussing the substantial evolution in Venetian chronicles or histories in the thirteenth century, it is important to explore the documents available prior to this period in order to highlight the similarities and differences that come in the thirteenth century. The earliest surviving Venetian chronicle is John the Deacon's, from the early eleventh century, which

\footnotetext{
${ }^{270}$ Brown, "The Making of Byzantine History,” 146.

${ }^{271}$ Brown, "The Making of Byzantine History," 146.

272 Brown, "The Making of Byzantine History," 147.

${ }^{273}$ Brown, "Self Definition of Venetian Repubic," 513.

${ }^{274}$ Patricia Fortini-Brown, Venice and Antiquity, 24.
} 
described the origin of the only major city in medieval Italy that could not boast a Roman foundation. ${ }^{275}$ For another three hundred years the Venetian sense of time would be dominated by the necessity to invent a civic past, this need was met through visual or monumental, as well as textual means, it is evidenced in chronicles and histories of the city and influenced the articulation of the urban environment. ${ }^{276}$ Already in the twelfth century, the nature and content of the Venetian chronicles was changing, as was the political climate just not with the same intensity as in the thirteenth century, and the austere and fairly accurate writings of John the Deacon from the eleventh century would not suffice. The Origo, also known as the Chronicon Altinate and the Chronicon Gradense, offered more richly articulated and satisfyingly detailed account of a primitive foundation of the city, predating both early Christian and Roman pasts. ${ }^{277}$ This appeared in its first redaction around 1081 and underwent at least two revisions by the twelfth century. This document is regarded as a faithful mirror of the current mentality of the Venetians of the period.

Three themes in the Origo are particularly revealing of a developing historical consciousness within the ruling elite which would culminate to its fullest in the thirteenth century. The first theme is the deepening of the Venetian roots to archaic times by its decent from Troy. ${ }^{278}$ The second theme involves the cultivation of Venice's Christian roots, this text places the invasion of Aquilea a century earlier and claims that it was not the Longoboards but Attila the Hun who had driven the Christian descendents of the original Trojan settlers from their homes in the cities of the terra firma. This specified the Venetians as specifically Christian refugees from the pagan invaders. Finally, these immigrants now have specific identities as the

\footnotetext{
${ }^{275}$ Fortini-Brown, Venice and Antiquity, 11.

${ }^{276}$ Fortini-Brown, Venice and Antiquity, 12.

${ }^{277}$ Fortini-Brown, Venice and Antiquity, 12.

${ }^{278}$ Fortini-Brown, Venice and Antiquity, 13.
} 
Origo places emphasis on the lineage of the refugees. This is the first vivid sense in Venetian historiography that the city is defined as community as affluent, Christian men. ${ }^{279}$

It is in the thirteenth century that the Venetian self-concept reached a critical phase of elaboration and the formation of civic identity takes place. The legend was refined and further adapted under Andrea Dandolo in the fourteenth century but all of the basic paradigms were complete in the thirteenth. ${ }^{280}$ In this period Venice was entering its place in the Mediterranean world in the ranks of world powers, thus it seems logical that historiographical aspirations were heightened to match Venice's new role as a colonial empire, to go beyond emulating and appropriating the myths of other cities or empires in favor of creating a legitimizing and uniquely Venetian one. The most blatant aspects of this period are the visual ones seen in the retrospective current in art and architecture of the period, the facet which is most explored here, but contemporary with these and of equal importance are the chronicle counterparts to these visual narratives.

This fabrication and reworking of the past found its most eloquent expression in the third quarter of the century in Martino da Canal's Estoires de Venise written between 1265 and 1272, published in $1275 .{ }^{281}$ The retrospective current in art that seems to be forging and imitating early Christian art in Venice at this time had been active for decades, although this tale is produced almost simultaneously with the mosaics of the Cappella Zen, and the second and third Joseph cupolas in San Marco. In the prologue to this chronicle Canal makes plain the intention of his work so that "All would know of the deeds of the Venetians, and who they were, and whence they had come, and who they are, and how they built the noble city that is

\footnotetext{
${ }^{279}$ Fortini-Brown, Venice and Antiquity, 14.

${ }^{280}$ Brown,"Self Definition of Venetian Republic," 512.

${ }^{281}$ Fortini-Brown, Venice and Antiquity, 24.
} 
called Venice that is truly the most beautiful in the world." ${ }^{282}$ Also significant is Canal's use of French, the first history to be written in Italy which makes use of the volgare, a significant break in tradition. ${ }^{283}$ This was by no means the language of the common Venetian, it was actually the language used at the French court, but it ensured maximum accessibility among the literate upper class. This enriching of the historical record was a way of ennobling the civic past and justifying the entrepreneurial present. ${ }^{284}$ In this chronicle he incorporates both the foundational myths of Attila the Hun as well as the Trojan traditions which he refined and embellished into a single, elevated agenda. ${ }^{285}$ The humble past of Venice was forgotten in favor of an affluent beginning where the new inhabitants constructed great churches and monasteries of gold and precious materials.

The portion of Canal's chronicle which most strikingly coincides with the art of San Marco, not only in its renaissance of early Christian art, but in the creation of a new aspect of Venetian history altogether: the legend of the predestinatio. This story made a concurrent debut in chronicle and mosaics, as well as in the sculpture of St Mark's vision of the angel in the tympanum above the main entrance to the basilica of San Marco. ${ }^{286}$ This story confirmed not only ancient, free, or holy foundations, but that the city enjoyed a divinely sanctioned destiny from the time of Christ. ${ }^{287}$ Venice in these mosaics was going beyond connection to the apostolic age and claiming a model for their destiny into the antiquity of the Old Testament. These mosaics are used as testimony or proof to the events they portray, not just pictures to delight the senses, or to remind the beholder of a history already known and proven, but a proof in itself. This is illustrated as Canal instructs his readers "if some of you wish to verify that those

${ }^{282}$ Martino da Canal, Les Estoires de Venise: Cronaca veneziana in lingua francese dalle origini al 1275, ed. Alberto Limentani, (Florence, 1972), 2-3.

${ }^{283}$ Fortini-Brown, Venice and Antiquity, 24.

${ }^{284}$ Brown, Venice and Antiquity, 24.

${ }^{285}$ Brown, Venice and Antiquity, 24.

${ }^{286}$ Fortini-Brown, Venice and Antiquity, 24.

${ }^{287}$ Fortini-Brown, Venice and Antiquity, 24. 
things that happened just as I told you, come to see the beautiful church of San Marco in Venice, and look at it right in front, because this story is written here just as I have told you."288 At the end of the thirteenth century, in 1292 another chronicler known as "Marco" began writing his own history of the city, and in it we can see how this myth was further developed as time went on, further disconnecting from Aquilean connection as well as firmly placing the date of foundation 454 years prior to Rome. ${ }^{289}$

Venice was not alone; the thirteenth century was a time of heightened consciousness in all of Italy concerning civic origins. In Perugia Nicola and Giovanni Pisano completed works equivalent to encyclopedias in stone documenting her mythic beginnings in the Roman era as well as her pious Christian present. ${ }^{290}$ Similar instances can be seen in Genoa, Ravenna, Bologna, Brescia, and Turin, who all claimed mythical beginnings either as distinguished Roman cities or as originating prior to Rome by figures such as Janus or Tubal. Perhaps this is displayed most boldly in Milan, whose historians placed the foundation 932 prior to Rome, specifically Bonvesin de la Riva writing in 1288, who claimed the papacy should move from Rome to their own fair city. It is clear that Venetian self-fashioning is not singular among thirteenth-century Italian citystates, yet it remains unique to the Venetian state and was a major contribution to the consolidation of the Venetian civic identity. ${ }^{291}$

Although the Venetians are not unique in their attempts at self-fashioning and historical manipulation, they are unique in their strong use of not simply apostolic connection, but of Old Testament connection, as well as the use of predestination concerning both the presence of St Mark and the conquest of Constantinople. Venice, as the state with the shallowest history among the Italian states was contending not only with refashioning or representing its ancient and

\footnotetext{
${ }^{288}$ Canal, Estoires, 20-21.

${ }^{289}$ Fortini-Brown, Venice and Antiquity, 25.

290 Fortini-Brown, Venice and Antiquity, 25.

${ }^{291}$ Fortini-Brown, Venice and Antiquity, 25.
} 
legitimizing past, but creating it from scratch. Also unique to Venice was the importance of disentangling Venetian history and claims to power from the histories of Aquilea and Constantinople. These cities were once entities that Venice drew upon as it developed myths of origin and ecclesiastical authority. In the thirteenth century, events had led to a new priority in Venetian historiography; these emerged after the distancing of Venice from a good relationship with the Pope, the extinguishing of the former relationship with Byzantium in 1204, and its rising authority due to its maritime dominance and commercial wealth. All of these changes had given Venice a new sense of power and independence which required a distancing from former cultural dependencies as well as a stronger, more profound ancient Christian past which could justify the power of the Venetians in this era. They had defined themselves in this century not only as the predestined home of St Mark, but as the rightful and destined usurper of Byzantine power as predicted by Constantine, and as such the inheritor of the ancient Christian legacy of Byzantium.

When considering the shift in the thirteenth-century chronicles from former redactions of Venetian history, as well as the noted archaic style in art of the period it becomes apparent that behind all of these works there is a strong and irrefutable drive to deal with history through public art and writing. The manner of dealing with history, heritage, and the past in Venice is something which has concerned scholars and is a constant source of complexity in dealing with Venetian art. To the largest extremes this attempt in the thirteenth century to represent a more ancient historical foundation through art and monuments is expressed through the copying of ancient works which can be seen in several Byzantine relief sculptures, the copies of which are hard to distinguish from the original. ${ }^{292}$ This meticulous Venetian copying of early Christian works, including the use of the Cotton Genesis as a miniature model, the display of genuine ancient

292 Demus, “A Renascence of Early Christian Art,” 39. 
spolia from Constantinople, themes of typology and prophecy in the Old Testament cycle, and even the reformulation of Venetian foundational history are all coming from a uniquely medieval concept of the past and the use of it in writing and art for political purposes.

The fact that Venice was creating its own ancient past is not new to the thirteenth century. Traces of this can be seen back to the theft of Mark's relics, and very clearly in the chronicles, art, and histories of the eleventh and twelfth centuries, the issue at hand is how and why this self-fashioning changed courses in the thirteenth century. Also of importance is the worldview which would not only allow this sort of refashioning of history, but also call for it as the future of Venice as an empire became more imminent. Even in the eleventh-century chronicles of John the Deacon it is apparent that Venice had transformed itself from an outpost of the Byzantine Empire to a more independent republic. ${ }^{293}$ Yet, after the conquest of Constantinople and the events of 1177 it became clear that Venice no longer had to turn to Byzantine or Roman antecedents to appropriate a past which could legitimize it as an influential merchant republic, it could establish a history which was holier and more ancient then either.

The foundation on which medieval government is built required interplay with history, thus historiography played an important role in the politics of a medieval society which was consistently dependent on the past for current legitimacy. ${ }^{294}$ Not only the present institutions but the future success of the Empire was believed, in the Middle Ages, to be determined by its early development, and in the case of Venice, in times previous to its development through prophecy and typological references made in the art and chronicles. ${ }^{295}$ The identity of a republic, empire, or nation focused on the past as well as finding a legitimizing role, as did many

\footnotetext{
293 Pincus, The Tombs of the Doges, 4.

${ }^{294}$ Gabrielle Spiegel, "Political Utility in Medieval Historiography: a Sketch." History and Theory (1975), 314. ${ }^{295}$ Brown, 146.
} 
Italian city-states in this era, within the Greco-Roman world. ${ }^{296}$ The importance in investigating this medieval preoccupation with history as it affects Venice is that it exposes within the visual histories the underlying beliefs and techniques of expressing and dealing with the changing political standing during Venetian assent to world power. ${ }^{297}$

Gabrielle Spiegel in her study of the Political Utility of Medieval Historiography, discusses at length the medieval relationship with the past, a topic which speaks strongly to the subject of a changing attitude of Venice towards history as its political goals and abilities outgrew the previously constructed myths of foundation. Medieval social life was governed by historical precedent, but even more inherent is the manner in which it affected medieval government. In theory, medieval government originated in the divine will of God, and this idea of an "extra temporal" dimension of medieval politics was played out in the promissione of the Doge, or even more pointedly, the manner in which the Doge's power was explicitly bound to that of St Mark. ${ }^{298}$ This was displayed through the ceremony of the Doge when he was invested with the vexillium of St Mark at the high altar of San Marco immediately above the Evangelist's relics. In a general way, divine right to rule or to hold power, remained the foundation of political legitimacy throughout the medieval period, thus feeding the need for foundational legitimacy or "signs" of being a "Chosen People" or Empire. ${ }^{299}$ In this sense, there is a dichotomy between an obsession with the past as well as an ability to manipulate or draw typological conclusions from unrelated events from history. The belief that God created events of the past in order to signify the future simplified the need for a historical legitimacy by working within a typology drawn from the medieval and early Christian treatment of the Bible.

\footnotetext{
296 Brown, 146.

297 Spiegel, 314.

298 Spiegel, 315.

299 Spiegel, 315.
} 
Within the medieval concept of time the practice of historiography was not merely a record of facts or events, but a manner in which the actuality of history could be created. This can be seen most clearly in sources which represent the past in a manner which links it to the present. ${ }^{300}$ The archaic style of the Venetian mosaics of the thirteenth century clearly works to connect the current position of Venice with both early Christian and pre-Christian historical models and histories. These archaic images do not represent an inability to innovate and create. In fact, the more accustomed the mosaicists got to translating the miniatures of the Cotton Genesis to a monumental form, the more innovative they became, and the more the program shifts from careful reproduction to a work of purely thirteenth-century style and motivations.

These imitations and appropriations display a compelling necessity to find in the past a means to explain and legitimize the deviations from their previous position as a privileged daughter of the ancient Christian empire of Byzantium, to a position as "Lord of Three-Eighths of Byzantium" and possessor of the valued relics of Constantinople alongside those of St Mark. ${ }^{301}$ After 1204 the Venetians could claim that the power invested in Constantine's relics, as the True Cross and other ancient relics had been taken as spoils in the Fourth Crusade. ${ }^{302}$ The chronicler Marco, writing in 1290, found prophetic sanction for this idea, when Constantine set up his column, Marco affirms, he inscribed text on its base, foretelling the city's fall to the Latins when the cross fell from its summit. ${ }^{303}$ The Venetians fulfilled this promise when they helped conquer Constantinople in 1204.

When considering these changes in Venetian political standing, and the attempt connect this with the artistic and historical changes at this time, it is necessary to recognize that beyond

\footnotetext{
${ }^{300}$ Hans-Werner Goetz, "The Concept of Time in the Historiography of the Elevent and Twelfth Centuries." Medieval Concepts of the Past. Ed. Gerd Althoff, Johannes Fried, and Patrick J. Geary. (Cambridge: Cambridge Up, 2002, 134.

301 Spiegel, 315.

302 Dale, "Stolen Property,” 212.

${ }^{303}$ Dale, "Stolen Property," 212.
} 
the medieval fascination with history and foundational legends, the Middle Ages were characterized by both a historical and a typological mindset. ${ }^{304}$ In the Old Testament cycle and its use of an early Christian model it is plain that this typological mindset, as it pertains to the Bible and Old Testament events, was present during the era of the Cotton Genesis, but as seen in the Creation Cupola these tendencies were exaggerated as was popular in later medieval thinking. Individuals of the Middle Ages did not consider themselves separate from this concept of time experienced in typological analysis of the Bible, there was still a sense of time as a course of universal and salvational history which began at Creation and continued in thirteenth-century Venice, to one day be completed in the Second Coming. ${ }^{305}$ This explains the rich use of forgeries, historical legends, and myths in medieval political life. ${ }^{306}$ The legends created in Venetian chronicles and in the mosaics of San Marco illustrate the manner in which quasihistorical traditions can be shaped to present needs. ${ }^{307}$

Unique to the San Marco mosaics are the visual allusions which tie the history of St Mark and the Venetians to Old Testament examples. Although many medieval governments made significant attempts to lay claim to Roman or early Christian history, often through the theft of relics, the references of San Marco that connect Venetian institutions to prophetic Christian myths and Old Testament models is a uniquely complex effort among foundational myths. This malleability of history within the medieval mindset, and ability to connect history no matter how ancient, was fruitful in the establishment of the Venetian identity. The past could be a vehicle for change, all that was needed was to recreate it in the image of the present and claim its authority for legitimization of current practices or institutions. ${ }^{308}$ The medieval chronicler, or

\footnotetext{
${ }^{304}$ Goetz, 157.

${ }^{305}$ Goetz, 165.

${ }^{306}$ Spiegel, 316.

${ }^{307}$ Brown, 154.

${ }^{308}$ Spiegel, 316.
} 
mosaicist, utilized a very fluid perspective with regard to past and present, shaping a vision of the past that could be manipulated and supply legitimacy to the present. The concept of the past in these mosaics was one deeply based in the Christian belief and sense of time, thus in representation of historical events typological comparisons were permissible. ${ }^{309}$ The sense that time belonged to God and could be changed and molded, made the lines between past, present and future blurred. ${ }^{310}$

These forgeries of the Venetian past, of early Christian art, and the use of early Christian models are important to understanding the current in Venetian self-identity regardless of their deceitfulness. As Giles Constable asserts, works of this nature hold a "mirror to the period in which they were made." ${ }^{311}$ With the mix of displayed forgeries and spolia from Constantinople it is possible to detect the desire of the era in what they were copying or using as emblems. Once, in the eleventh and twelfth centuries the models for Venetian art lay in Byzantium, an empire with which Venice enjoyed special privileges and was emulating in order to utilize their legacy and antiquity. Yet in this century, after the conquest of Constantinople and the overall growth of the Venetian empire through Crete, Dalmatia, Zara, and other holdings, emulation of Byzantium was left behind in favor of the pre-Christian and early Christian myths or copies present in San Marco. In this sense it is clear why Constable asserted that "forgeries or plagiarism follow rather then create the fashion of their time and can without paradox be considered among the most authentic products of their time." 312 He is insisting that this level of effort to imitate or even forge history or art is one of the clearest indicators of the political or ecclesiastical desires in a medieval state, and that they offer their own value as a historical source. Just like miracles (such as the apparatio), visions (such as those of St Mark, Joseph, or Abraham), and other works of

\footnotetext{
${ }^{309}$ Goetz, 164.

${ }^{310}$ Constable, 156.

${ }^{311}$ Constable, 1.

${ }^{312}$ Constable, 2.
} 
social imagination, forgeries serve to justify profound social needs and reflected hopes of the people of the Middle Ages. ${ }^{313}$

Many scholars have recognized the Republic of Venice as a very unique entity in its abandonment within self-fashioning in this era of both Byzantine and Roman origins. ${ }^{314}$ As discussed, Venice was not the only Italian city-state to create a fictitious past, yet it is the only one to set roots outside of the Roman Empire. At this time of refashioning, upon gaining status as a colonial empire, Venice represented herself as the first republic of the new era, destined to be the historical successor to pagan Rome, born into Christian liberty. ${ }^{315}$ It is unique and noticeable that Venice chose at this point to highlight the fact that it was not of Roman foundation in its legend of Trojan foundation, dispersal by Attila the Hun, and arrival in Venice, as a pious and wealthy people. Slowly, prior to the Fourth Crusade Venice had asserted itself as a separate entity from Byzantium as well, and in the end asserted superiority, David Rosand speculates that Venice aspired not to be a "New Rome" or "New Constantinople" but a "New Jerusalem" and a city beloved by God. ${ }^{316}$

Once the purpose of these shifting historical images is established, it is necessary to ascertain that they were truly intended to inspire and represent this shift within the venue of San Marco. In this medieval context Constable asserts that "people lived in the past in a very real sense." ${ }^{317}$ Due to this connection with the past the art, architecture and ceremony of an environment such as San Marco could create closeness, and at times an identity, with history. The typological function of historical events was so much a part of experiencing historical accounts that such blatant references would not have gone unnoticed, such as on the façade, the

\footnotetext{
${ }^{313}$ Constable, 3.

${ }^{314}$ David Rosand, Myths of Venice: the Figuration of a State, (Chapel Hill \& London: The University of North Carolina P, 2001), 5.

${ }^{315}$ Rosand, Myths of Venice, 6.

${ }^{316}$ Rosand, Myths of Venice, 13.

${ }^{317}$ Constable, 49.
} 
Cappella Zen, which leads directly to the account of the Chosen People, the story of Abraham and his preference for the younger son as well as the Gentiles, or even the Creation Cupola with its clear early Christian references and typology. The line between myth and history, just like the line between past and present, in Venice was thin but through the use of documents and visual imagery the difference between myth and history could be obliterated, turning mythical past into historical fact by giving myth meaning in broad historical narratives. ${ }^{318}$ There was no sense that the events in the Joseph narrative, or in the story of the Chosen People directly led to the fate of Venice, but within this Christian view of time and typological reference the events of the past can create models which legitimize the events of the present or future. The old event foreshadows the new event, thus the past becomes a prophecy and the present becomes a "predeterminant." 319 In the predestinatio legend the rise of Venice is literally prophesied before the Evangelist, but in more subtle ways, which were part of this typological mindset, much of the atrium mosaics play this prophetic role as well, legitimizing the current role of Venice.

The shift in Venetian historiography and historical imagery may be summarized in the words of Patricia Fortini-Brown, in Venice "historiographical aspirations were heightened to match Venice's new role as a colonial empire." ${ }^{320}$ It is not surprising that this shift was expressed in art as well as historical writing, affecting the communal memory of Venetian foundation in the images at San Marco. Art was the strongest and most far reaching medium for influencing the opinions and memories of a medieval population or culture, especially in a site such as San Marco. As discussed throughout this paper, the site of San Marco was of enormous value culturally, religiously and politically. In fact, in psychological investigations it has been found that there are certain historical "memory sites" in which the memory of the entire nation or religious

\footnotetext{
${ }^{318}$ De Vivo, 165.

319 Siegel, 321.

${ }^{320}$ Fortini Brown, "Self Definition of the Venetian Republic," 514.
} 
community is played out or represented, a place where the communal or cultural memory is molded, in San Marco this is done through visual imagery. ${ }^{321}$ This means of artistic representation as a historical source in the Middle Ages is one whose potency cannot be overstated, images in this culture were "signposts specifically designed to guide the mind to higher truths." ${ }^{322}$ It is clear that the worldview of medieval citizens would have been conducive to understanding the intentions of these typological and prophetic mosaics installed in San Marco, and that a visual method is one which was equal to or better than written narrative in creating historical truths within this Venetian self-fashioning. Once both the medieval understanding of history and the concept of imagery as an historical document are established it is possible to see these mosaics as works which express fundamental ideas concerning the nature of medieval political reality and its relation to the past. The past is utilized here to promote a new age of Venetian self-fashioning. This concept is asserted by Debra Pincus, who refers to this era as "the creative period of state celebration" in which there was a sense "of the fortunes of Venice under divine supervision tak[ing] visual form." ${ }^{323}$ It is here, in the thirteenth century, as imitation of other empires or cities is abandoned, that the culmination of the mythogenesis of Venice is established through visual imagery. ${ }^{324}$

The purpose of this study was to identify the purpose and impetus behind the shift which occurred in the imagery of the thirteenth-century mosaics within the ducal chapel of San Marco. The methods for reaching these conclusions were threefold, first, to identify the political and social factors which would lead to a new Venetian desire in self-fashioning. Second, to analyze the medieval understanding of concepts such as history, time, and imagery, that would make this shift not only possible but necessary. Third, to examine the iconography and cues

\footnotetext{
${ }^{321}$ Jan Assmann, Religion and Cultural Memory, (Stanford, California: Stanford UP, 2006), 15.

${ }^{322}$ Lamia, 27.

${ }^{323}$ Pincus, "Christian Relics and the Body Politic," 48.

${ }^{324}$ Pincus, "Christian Relics and the Body Politic," 50.
} 
within the mosaics in order to identify the message intended and received concerning this reconfiguration of Venetian history. In the drastically altered political climate of thirteenthcentury Venice it becomes clear why such changes would be necessary. Medieval Italy was a culture in which history and foundational myths acted as indicators of the present and future destiny of a people or nation. For Venice, a nation with growing success, and a noticeably shallow history, it became crucial to create a past and identity which justified the power gained by this republic in the thirteenth century. Venice had broken its once strong alliance with the Papacy, and was the power behind the overthrowing of the great Christian empire of Byzantium.

This shift produced a need for a more sacred and historically legitimate purpose for the Venetians, they had outgrown their previous foundational legends, and required a myth which could justify this newly powerful empire. This was an empire that was in control of the most ancient of empires and separated from the legitimizing blessing of the Papacy. Thus, Venice worked within medieval concepts of time and history, as a malleable tool of God's power and will, to create a new understanding of Old Testament events as well as a new legend of St Mark. This legend, represented in the most important of Venetian venues, succeeded in legitimizing Venice long before the theft of Mark's relics. In fact, this myth changed Venice into a nation founded by St Mark, and molded the furta sacra of his relics from an urban theft into a fulfillment of ancient prophecy from the era of Christ and the apostles.

This unique approach to foundational myth separated Venice, as Rosand described it not as a New Rome or New Constantinople, but as more then both: a New Jerusalem. Not only was Venice a predestined nation, which would inherit the glory of both Romes by the blessing of God, but the imagery in San Marco takes these allusions a further step by tying the prophecy of St Mark, and the foundation of Venice to Old Testament models. This relationship was achieved through various complex uses of visual cues and physical connections within the basilica, 
including the use of the early Christian Cotton Genesis. These cues were used to signal connections between the narratives of Venice and St Mark to the plight of the Chosen People from the creation of the world to the exodus from Egypt, which so closely mirrors the exodus of St Mark from Alexandria. The images of the atrium were prefaced by the new narrative of the life of St Mark, imagery which would have prepared the viewer to view the mosaics of the atrium in a specifically nationalistic manner. This may have ensured that visual parallels in the Old Testament would have been noticed and layered into the complex myth spun by Venice in this period. These visual allusions not only established a unique foundational myth but created a prefoundational myth which utilized typological references. These references were used in this instance to signal the Venetian people as a new "Chosen People" of God, a nation whose importance went far beyond their physical foundation and became part of a continuing salvational and biblical history, in a manner which may be unparalleled in the medieval Italian world. 


\section{FIGURES}

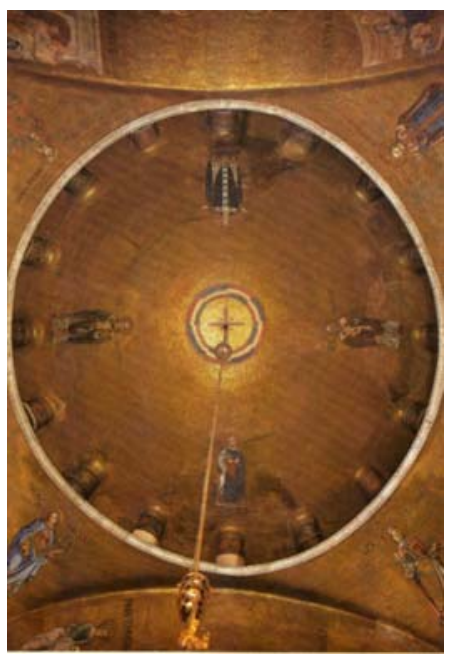

FigurE 1, SOUTH DOME, VIEW FROM BELOW, ELEVENTH CENTURY, DEMUS

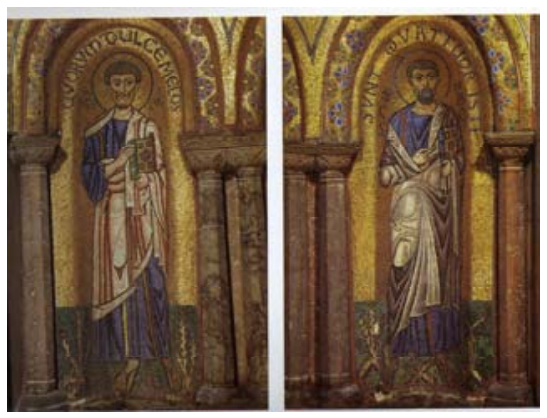

Figure 2, MAIN PORCH, SAINTS LUKE AND MARK, ELEVENTH CENTURY, DEMUS 


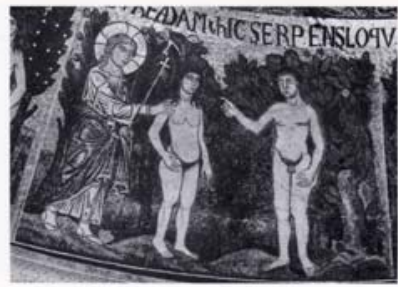

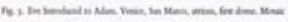

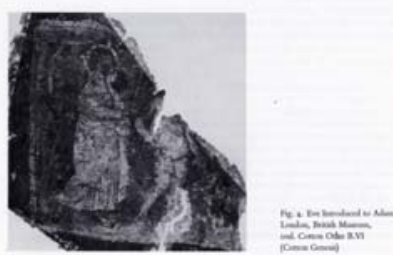

Figure 3, INTRODUCTION OF AdAM AND EVE, WEITZMANN

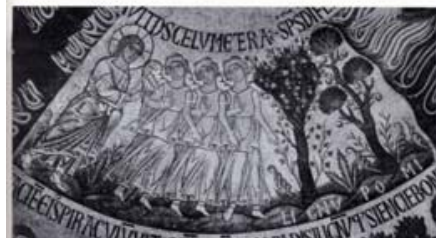

nis

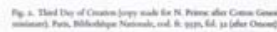

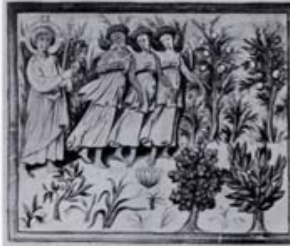

Figure 4, Third Day of Creation, or the Creation of the Plants, WeitzmanN

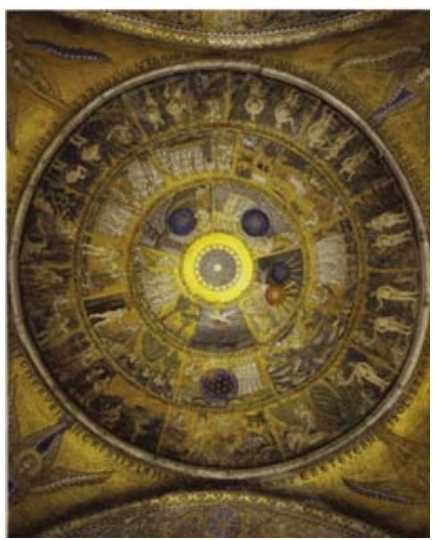

Figure 5, Creation Cupola, VieW From BELOW, Demus 


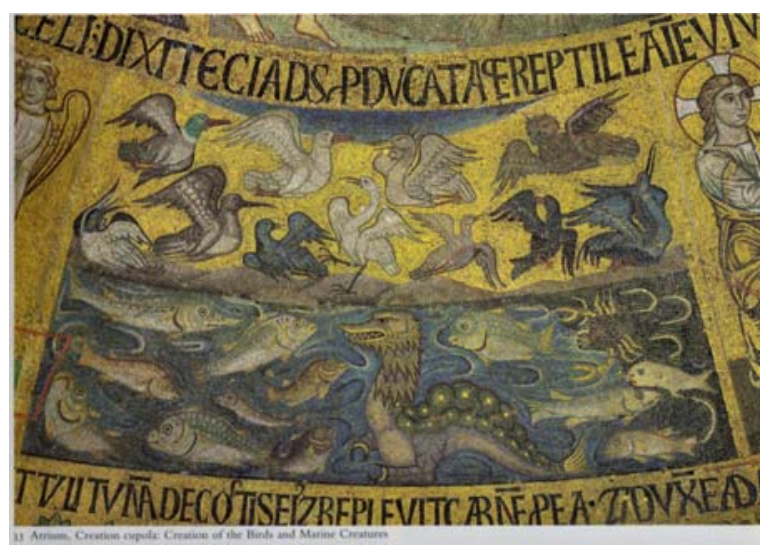

Figure 6, Creation of the Birds and Marine Creatures, Demus

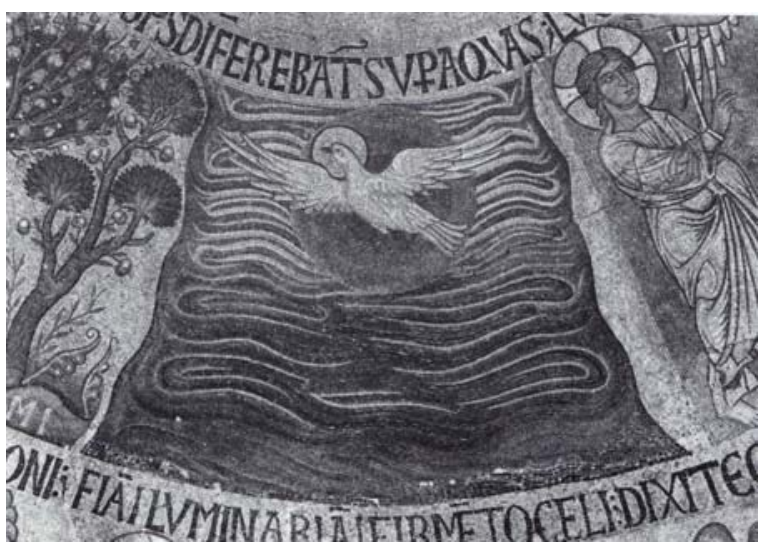

Figure 7, SPIRIT ABOVE THE WATERS, DEMUS

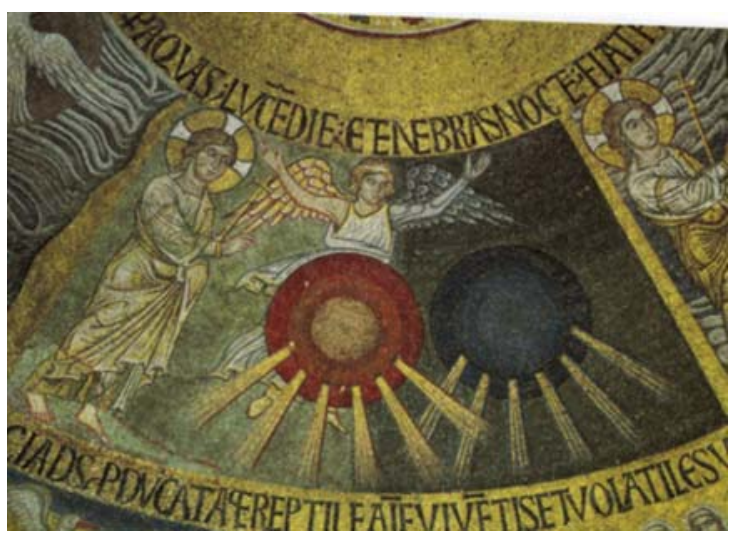

Figure 8, Separation of Light and Darkness, Demus 


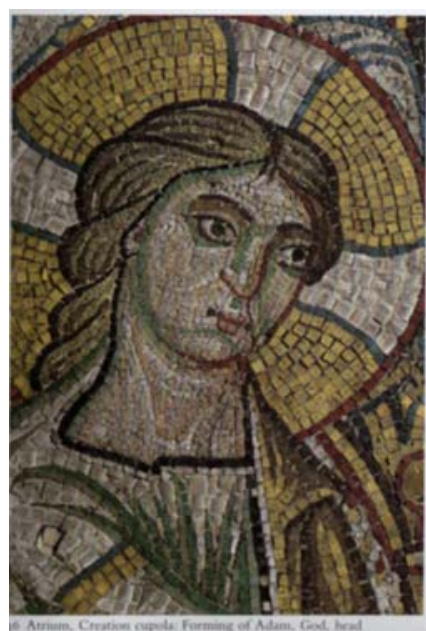

Figure 9, DetAil of Christ-Logos, From Forming of AdAM, DEMUS

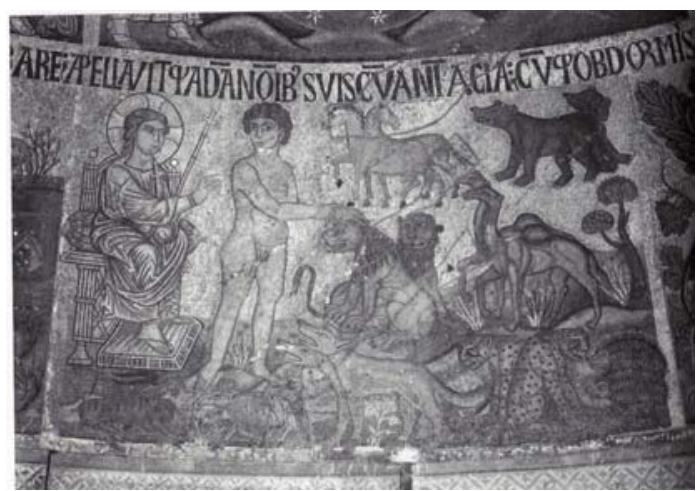

Figure 10, NAming of THE ANimaLs, Demus

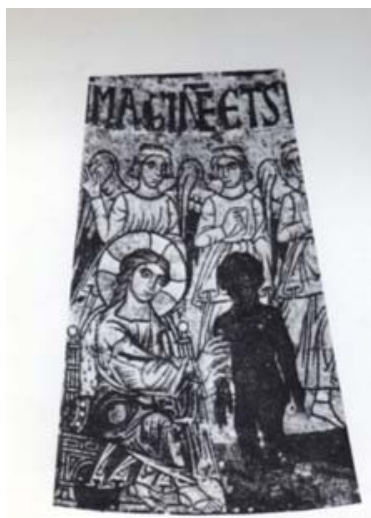

Fia 17. Shuping of Adam.

Figure 11, Formation OF AdAM, WEITZMANN 


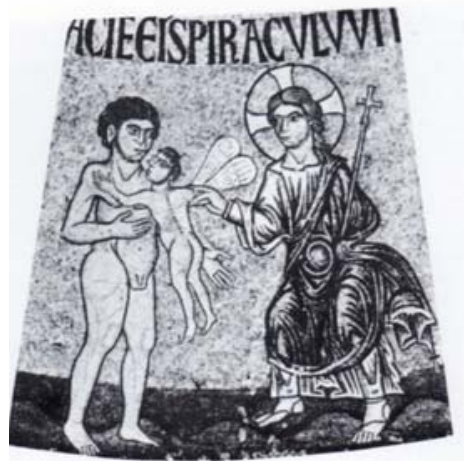

Figure 12, ANIMATION OF ADAM, WEITZMANN

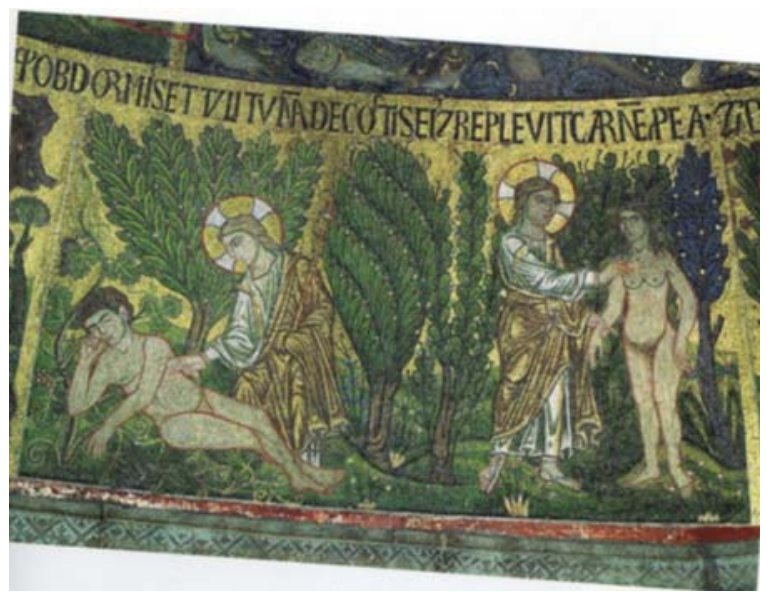

Figure 13, Creation of Eve, Howell

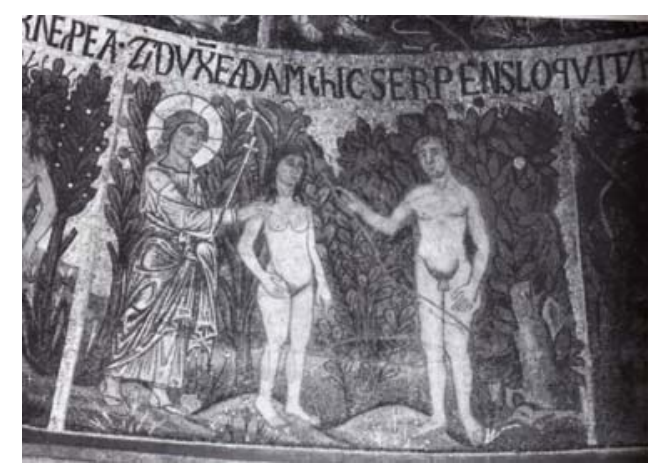

Figure 14, Introduction of AdAm AND Eve, Howell 


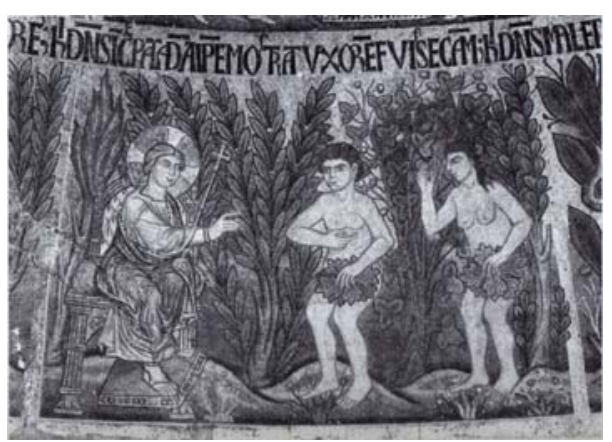

Figure 15, Denial of Guilt, Howell

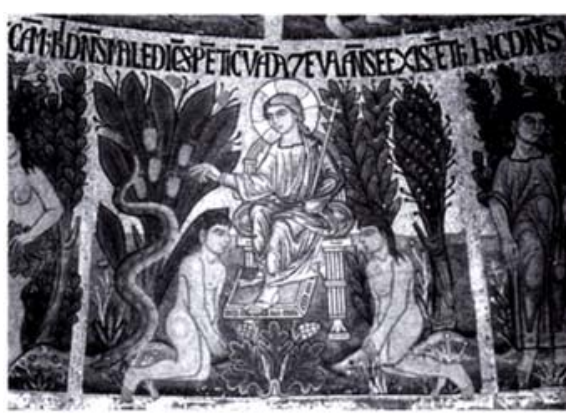

Figure 16, Judgment of AdAm AND Eve, Demus

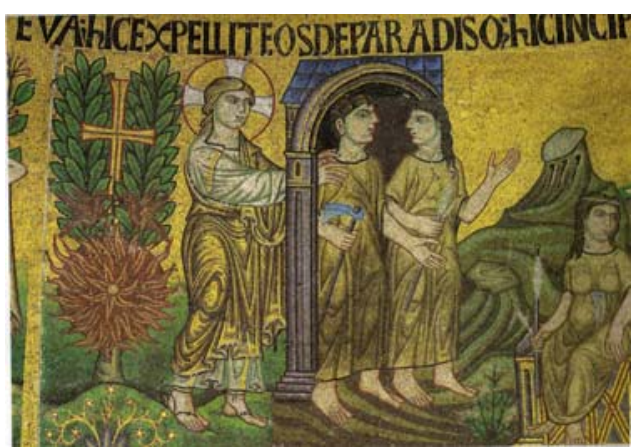

Figure 17, Expulsion of AdAM AND Eve, Demus

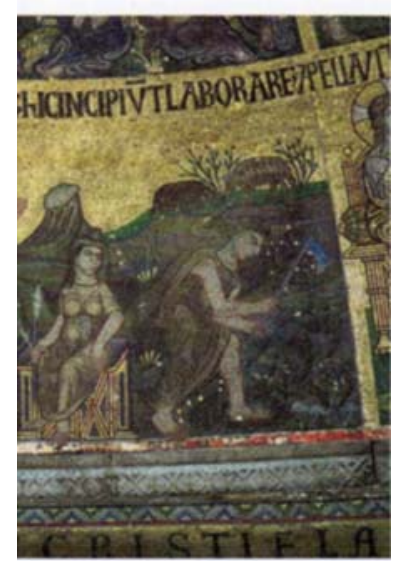


Figure 18, LABOrS OF AdAM AND Eve, DEMUS

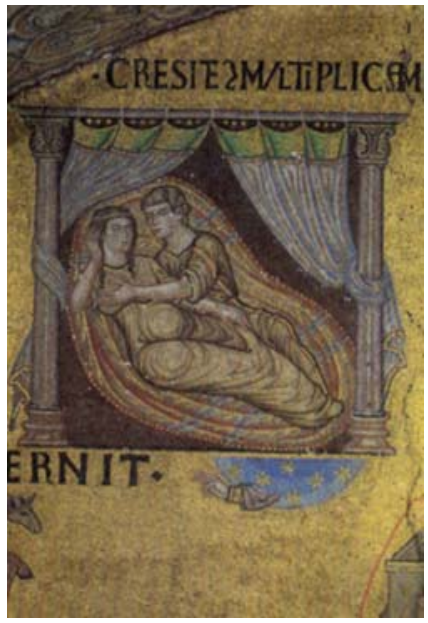

Figure 19, Begetting of Cain, Demus

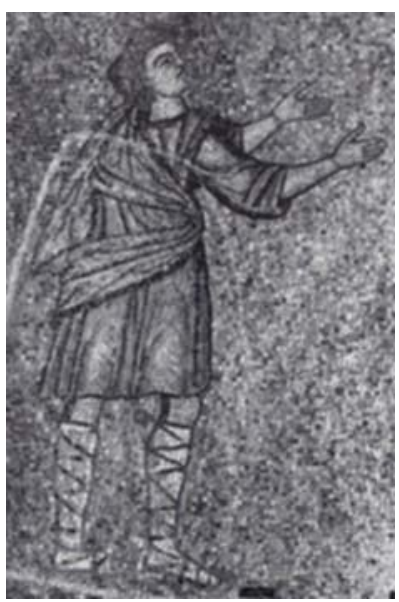

Figure 20, Curse of CAIN, Demus

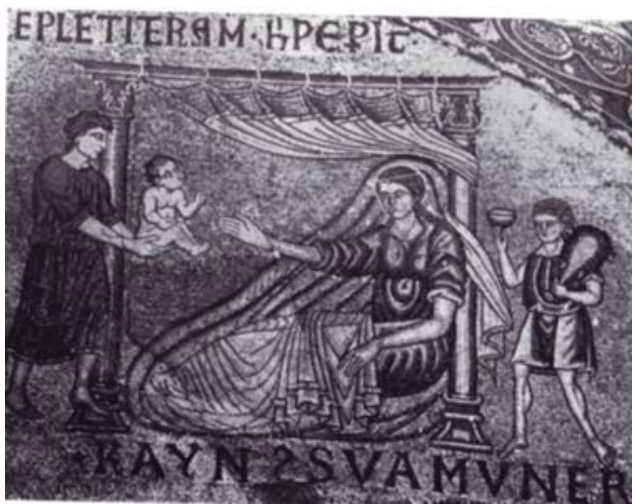

Figure 21, BirTH OF ABEL, DEMus 


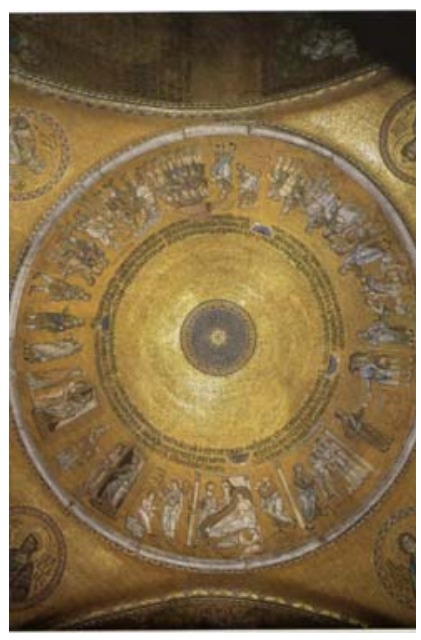

Figure 22, Abraham Cupola, Demus

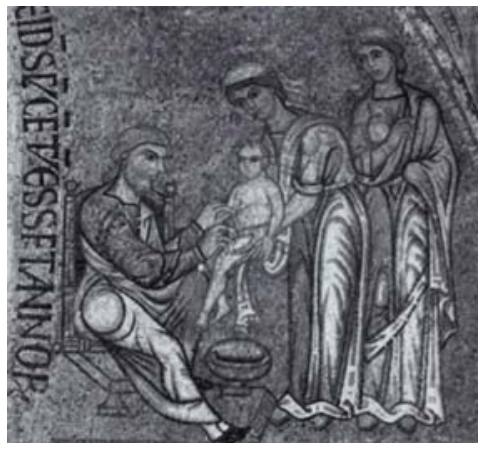

Figure 23, Birth and Circumcision of IsaAC, Demus

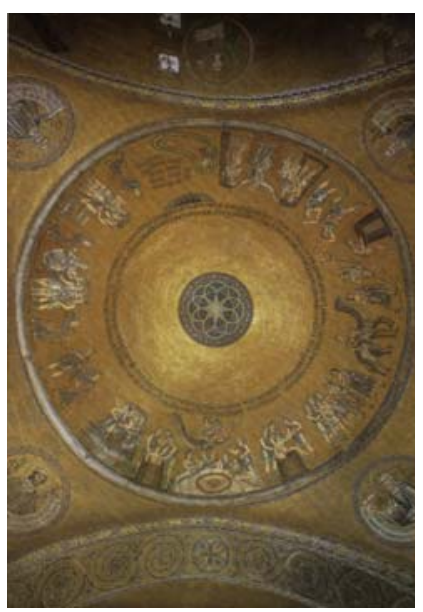

Figure 24, Joseph Cupola I, Demus 


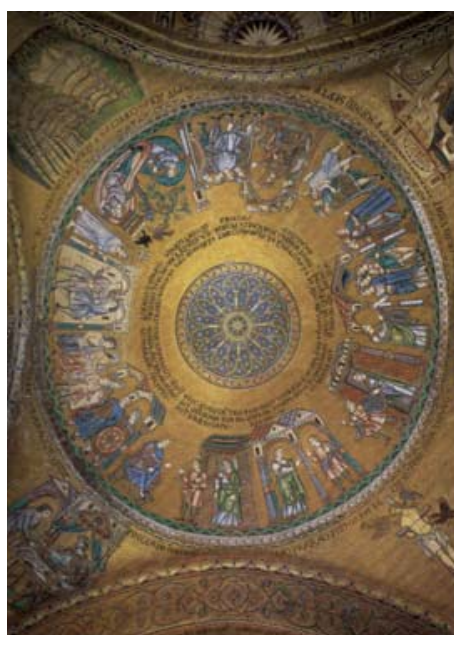

Figure 25, Joseph Cupola II, Demus

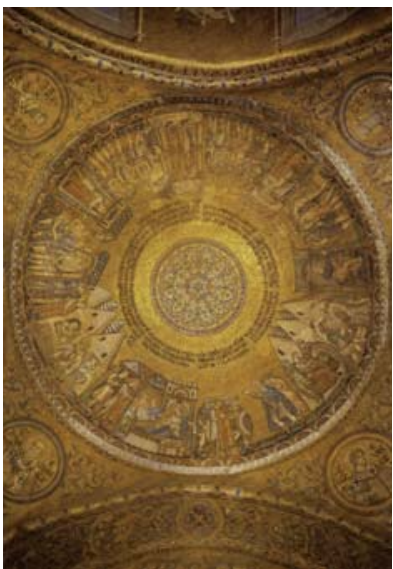

Figure 26, Joseph Cupola II, Demus

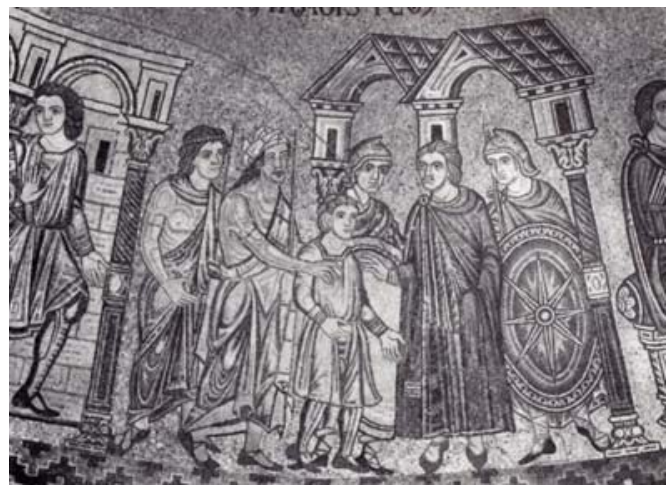

Figure 27, Joseph SOLD TO POTIPHAR, DEMUS 


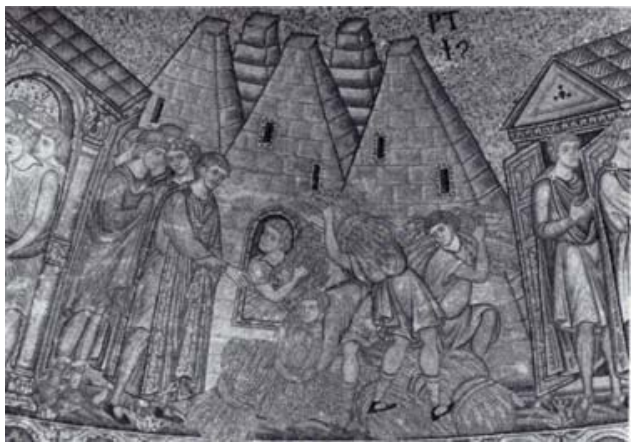

Figure 28, JOSEPH GATHERING CORN, DEMUS

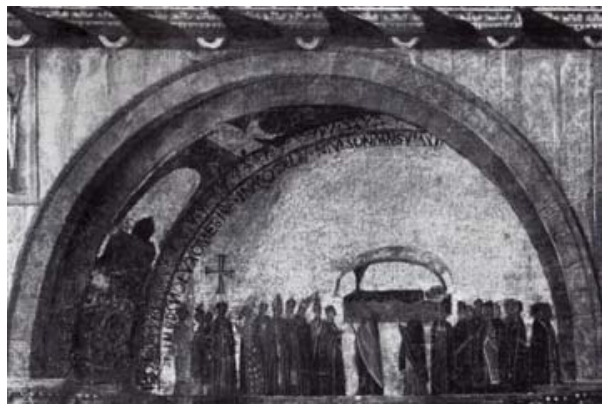

Figure 29, RECEPtion of MARK's ReLics By the Doge, Demus

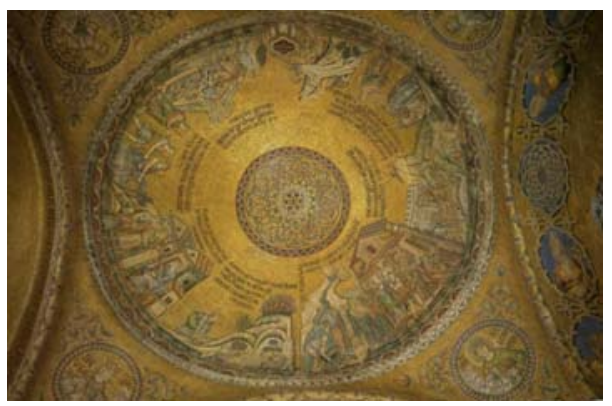

Figure 30, Moses Cupola, VIEW From Below, Demus

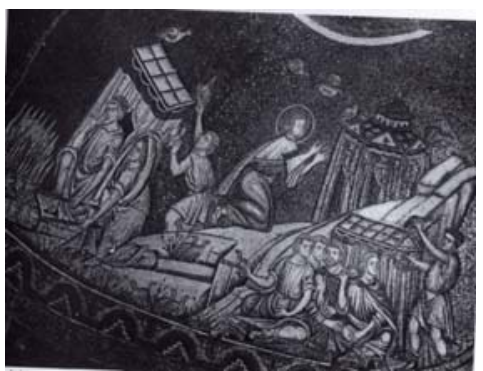

Figure 31, The Miracles of The Manna And the Quails, Demus 


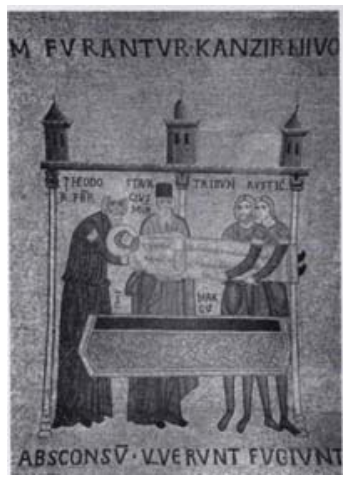

Figure 32, REMOVAL OF MARK'S BODY, DEMUS

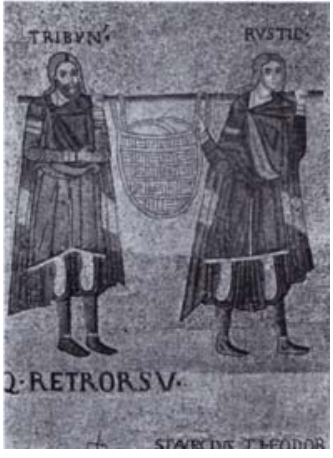

Figure 33, Transportation of Mark's ReLics, DEMUs

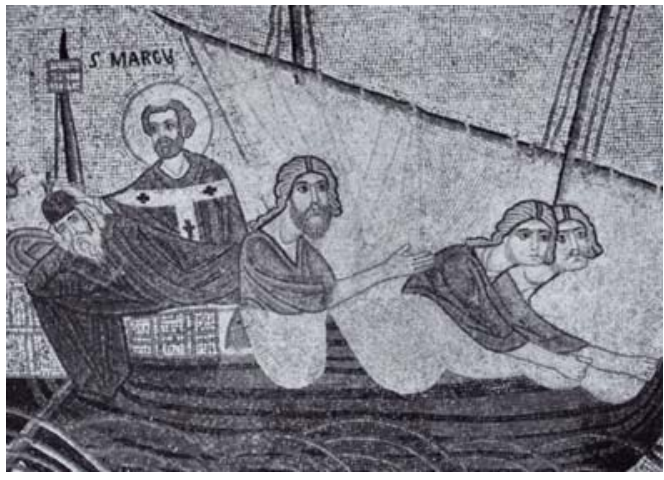

FIgURE 34, SHIP SAVED By MARK, DEMUS 


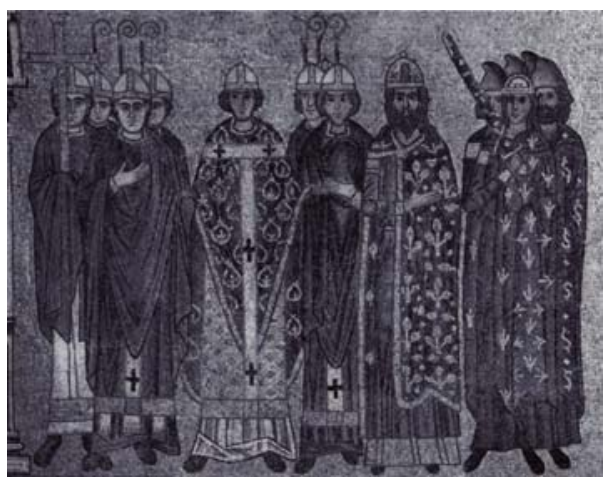

Figure 35, ReCEPTION OF MARK'S ReLics, Demus

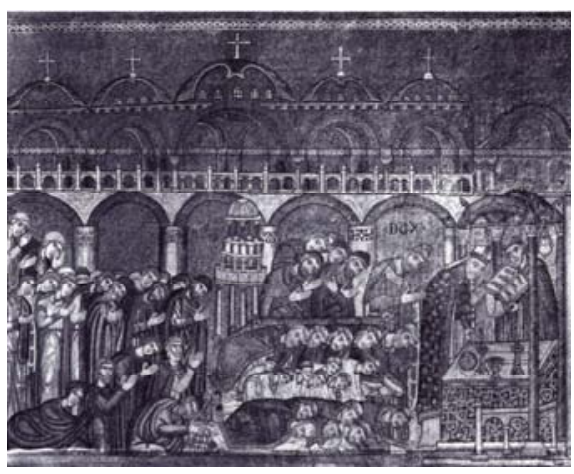

Figure 36, Prayers for the Discovery of the Body (PreghierA), Demus

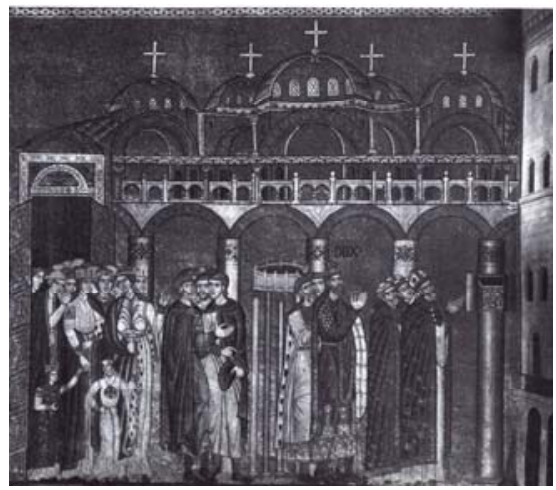

Figure 37, Discovery of THE RELICS (APPARATIO), DEMUS 


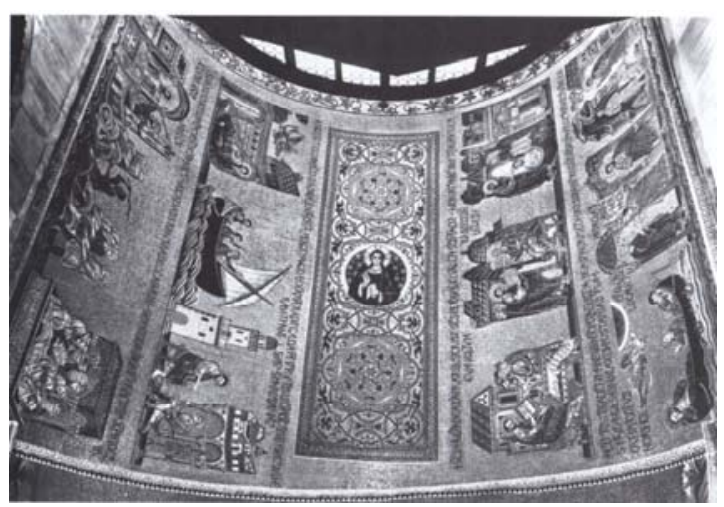

Figure 38, CAPpella ZEN, VIEW FROM BeLOW, DEMUS

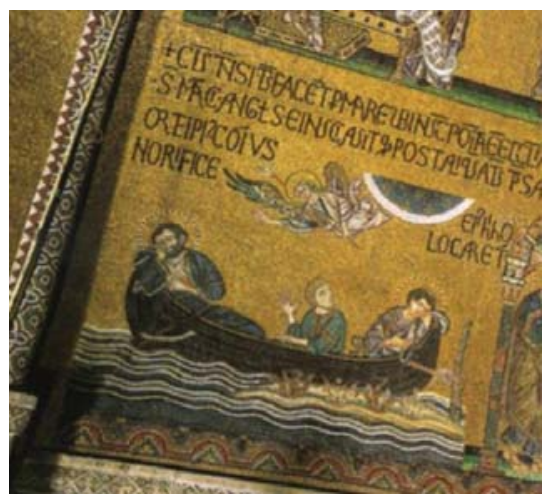

Figure 39, Legend of Mark (PREDestinatio), Demus 


\section{Works Cited}

Althoff, Gerd, Johannes Fried, and Patrick J. Geary, eds. Medieval Concepts of the Past: Ritual, Memory, Historiography. Cambridge: Cambridge UP, 2002.

Assmann, Jan. Religion and Cultural Memory, Stanford, California: Stanford UP, 2006.

Brown, T.S. "History as Myth: Medieval Perceptions of Venice's Roman and Byzantine Past." The Making of Byzantine History. Ed. Roderick Beaton and Charlotte Roueche. London: Variorum, 1993. 45-57.

Buenger Robbert, Louise. "Rialto Businessmen and Constantinople, 1204-1261." Dumbarton Oaks Papers 49, 1995. 43-58.

Constable, Giles. Culture and Spirituality in Medieval Europe. Variorum, 1996.

Da Canal, Martino. Les Estoires de Venise: Cronaca veneziana in lingua francese dalle origini al $\underline{1275}$, ed. Alberto Limentani, Florence, 1972.

Dale, Thomas A. "Inventing a Sacred Past: Pictorial Narratives of St. Mark the Evangelist in Aquileia and Venice." Dumbarton Oaks Papers, 48 (1994): 53-104.

Dale, Thomas A. "Stolen Property: St Mark's First Venetian Tomb and the Politics of Communal Memory." Memory and the Medieval Tomb. Ed. Elizabeth Valdez El Alamo and Carol Stamatis Pendergast. Aldershot, UK and Brookfield, VT: Ashgate, 2001. 205215.

Demus, Otto. The Mosaics of San Marco v.1-2, Ed. Kessler S. Herbert. Chicago and London, 1984.

Demus, Otto. “A Renascence of Early Christian Art in Thirteenth-Century Venice”. Late Classical and Medieval Studies in Honor of Albert Mathias Friend, Jr. Ed. Kurt Weitzmann. Princeton, New Jersey: Princeton UP, 1955, 348-362. 
Demus, Otto. "Venetian Mosaics and Their Byzantine Sources." Dumbarton Oaks Papers, 33 (1979): 337-343.

De Vivo, Filippo. "Historical Justifications of Venetian Power in the Adriatic." Journal of the History of Ideas 64, (2003): 159-176.

Ferrard, Christopher. "The Amount of Constantinopolitan Booty in 1204." Studi Veneziani XIII. Ed. Leo S. Olschki. Venice: Firenze, 1971. 95-104.

Fortini Brown, Patricia. "The Self-Definition of the Venetian Republic." City States in Classical Antiquity and Medieval Italy. Ed. Anthony Molho, Kurt Raaflaub, and Julia Emlen. 1991: The University of Michigan.

Fortini-Brown, Patricia. Venice and Antiquity. New Haven \& London: Yale UP, 1996

Geary, Patrick J. Furta Sacra. Princeton: Princeton UP, 1990.

Geary, Patrick J. Living with the Dead in the Middle Ages. Ithaca and London: Cornell UP, 1994.

Georgopoulou, Maria. "Late Medieval Crete and Venice: an Appropriation of Byzantine Heritage." The Art Bulletin 77.1 (1995): 479-493.

Goetz, Hans-Werner. "The Concept of Time in the Historiography of the Elevent and Twelfth Centuries." Medieval Concepts of the Past. Ed. Gerd Althoff, Johannes Fried, and Patrick J. Geary. Cambridge: Cambridge UP, 2002.

Grubb, James S. "When Myths Lose Power: Four Decades of Venetian Historiography." The Journal of Modern History 58.1 (1986): 43-94.

Hahn, Cynthia. "Visio Dei: Changes in Medieval Visuality." Visuality Before and Beyond the Renaissance. Ed. Robert S. Nelson. Cambridge, UK: Cambrdige UP, 2000. Harding, Catherine. "The Production of Medieval Mosaics: the Orvieto Evidence." Dumbarton Oaks Papers 43 (1989): 73-102. 
Hawkins, Ernest J., and Liz James. "The East Dome of San Marco, Venice: a Reconsideration." Dumbarton Oaks Papers 48 (1994): 229-242.

Christopher Hibbert, Venice: the Biography of a City. New York \& London: W.W. Norton and Company, 1989Hills, Paul. Venetian Colour. New Haven and London: Yale UP, 1999.

Howard, Deborah. The Architectural History of Venice. New Haven \& London: Yale UP, 2002. Howard, Deborah. Venice and the East. New Haven and London: Yale UP, 2000.

Howell Jolly, Penny. Made in God's Image? Eve and Adam in the Genesis Mosaics At San

Marco, Venice. Berkeley and Los Angeles: University of California P, 1997.

Jensen, Robin M. "The Fall and Rise of Adam and Eve in Early Christian Art and Literature."

Interpreting Christian Art. Ed. Heidi J. Hornik and Mikeal C. Parsons. Macon, Georgia: Mercer UP, 2003. 25-52.

Lamia, Stephen. "Synaesthesia, and the Sepulcrum Domini: Sensory Stimuli and Memory Stratagems." Memory and the Medieval Tomb. Ed. Elizabeht Valdez El Alamo and Carol Stamatis Pendergast. Aldershot, UK and Brookfield, VT: Ashgate, 2001. 19-29. Lane, Frederic, C. Venice: a Maritime Republic. Baltimore and London: The Johns Hopkins UP, 1973.

Lowden, John. "Concerning the Cotton Genesis and Other Illustrated Manuscripts of Genesis." Gesta 31.1 (1992): 30-41.

Madden, Thomas, F. Enrico Dandolo and the Rise of Venice. Baltimore \& London: The Johns Hopkins UP, 2003.

Madden, Thomas, F. "Venice, the Papacy, and the Crusades before 1204," in The Medieval Crusade, Susan J. Ridyard, ed. Woodbridge: Boydell Press, 2004. 85-95.

Maguire, Henry. "Adam and the Animals: Allegory and the Literal Sense in Early Christian Art." Dumbarton Oaks Papers 41 (1987): 363-373. 
McGregor, James. Venice From the Ground Up. London: Belknap P, 2006.

Miles, Margaret. Image as Insight, Boston: Beacon Press, 1985.

Mueller, Reinhold C. "The Procurators of San Marco in Thirteenth and Fourteenth Centuries: a Study of the Office as a Financial and Trust Institution." Studi Veneziani XIII. Ed. Leo S. Olschki. Venice: Firenze, 1971. 95-104.

Pincus, Debra. "Christian Relics and the Body Politic: a Thirteenth Century Relief Plaque in the Church of San Marco". Interpretazioni Veneziane: Studi di Storia dell'arte in onore di

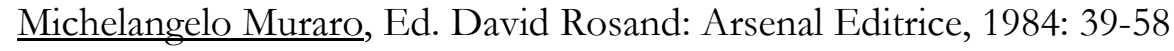

Pincus, Debra, The Tombs of the Doges of Venice. Cambridge, UK: Cambridge UP, 2000

Pincus, Debra. "Venice and the Two Romes: Byzantium and Rome as a Double Heritage in Venetian Cultural Politics." Artibus Et Historiae 13.26 (1992): 101-114.

Rodini, Elizabeth. "Mapping Narrative at the Church of San Marco: a Study in Visual Story Telling." Word \& Image 14.1 (1998): 387-396.

Rosand, David. Myths of Venice: the Figuration of a State. Chapel Hill \& London: The University of North Carolina P, 2001.

Rosand, David, "Venetia Figurata: The Iconography of Myth” Interprezione Veneziane: Studi di

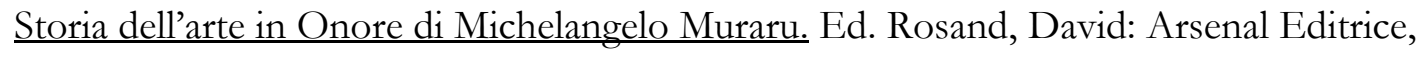
$1984,177-211$.

Sinding-Larsen, Christ in the Council Hall. Studies in the Religious Iconography of the Venetians. Rome: 1974.

Spiegel, Gabrielle. "Political Utility in Medieval Historiography: a Sketch." History and Theory, Oct $1975,314-325$.

Vio, Ettore, ed. The Basilica of St. Mark in Venice. New York: Riverside Book Company, 1999. 
Weitzmann, Kurt, and Herbert L. Kessler. The Illustrations in the Manuscripts of the

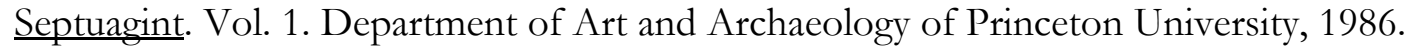

Weitzmann, Kurt, et al. The Place of Book Illumination in Byzantine Art. Princeton: Princeton UP, 1973.

Williamson, Jennifer J. The Joseph Cycle in the Atrium of San Marco, Venice. Washington UP, 1996. 